PNL- -8473

DE93 007178

\title{
Hanford Site Organic Waste Tanks: History, Waste Properties, and Scientific Issues
}

D. M. Strachan

W. W. Schulz

D. A. Reynolds

January 1993

Prepared for

the U.S. Department of Energy

under Contract DE-AC06-76RLO 1830

Pacific Northwest Laboratory

Richland, Washington 99352

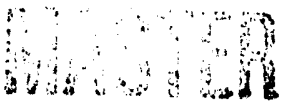




\section{Summary}

Eight Hanford single-shell waste tanks are included on a safety watch list because they are thought to contain significant concentrations of various organic chemicals. Potential dangers associated with the waste in these tanks include exothermic reaction, combustion, and release of hazardous vapors. In all eight tanks the measured waste temperatures are in the range 16 to $46^{\circ} \mathrm{C}$, far below the 250 to $380^{\circ} \mathrm{C}$ temperatures necessary for onset of rapid exothermic reactions and initiation of deflagration.

The actual amount of organic material currently associated with the tanks is unknown. Estimates are based on earlier measurements or computer code calculations. Brief fill histories are available for each tank, as is a list of all organic materials used at the Hanford Site from 1944 to 1980.

Studies in the 1970s indicated that organic materials with a high boiling point reacted vigorously and explosively at temperatures $>400^{\circ} \mathrm{C}$ if the $\mathrm{NaNO}_{3}$-organic mixture contained between 10 and $30 \mathrm{wt} \%$ organic material. The Hanford tanks were not thought to present a danger of ignition because the materials were not nitrated at the time of addition, the temperatures are below $175^{\circ} \mathrm{C}$, some volatile organics have been distilled off, and the low volatility of the major organic solvents inhibits ignition.

Only for Tank 241-C-103, in which there is very likely a separate layer of PUREX plant TBP-NPH solvent at the top of the aqueous waste in the tank, is there concern about the potential formation of flammable organic vapors in the head space. Several factors are thought to preclude initiation of an organic vapor fire in this tank: 1) the average temperature in the tank is $49^{\circ} \mathrm{C}$ while the flash point of a $30 \mathrm{Vol} \%$ TBP-NPH solvent is $77^{\circ} \mathrm{C}, 2$ ) there are no large heat sources in the tank, and 3) water vapor in the gas mixture above the liquid surface will inhibit combustion.

Investigation of the possibility of vapor release from Tank C-103 has recently been elevated to a top safety priority. There is a need to obtain an adequate number of truly representative vapor samples and for highly sensitive and capable methods and instruments to analyze these samples.

Remaining scientific issues include: - an understanding of the behavior and reactions of organic compounds in existing underground tank
environments

- knowledge of the types and amounts of organic compounds in the tanks

- knowledge of selected physical and chemical properties of organic compounds

- source, composition, quantity, and properties of the presently unidentified volatile organic compound(s) apparently evolving from Tank C-103. 


\section{Contents}

Summary $\ldots \ldots \ldots \ldots \ldots \ldots \ldots \ldots \ldots \ldots \ldots \ldots \ldots \ldots \ldots \ldots \ldots$ iii

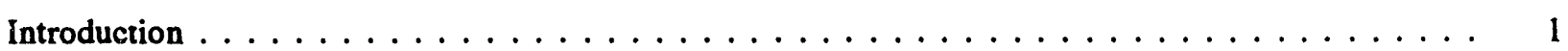

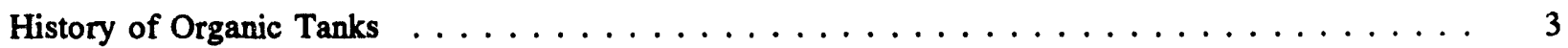

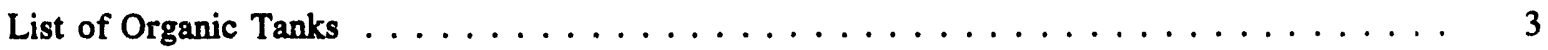

Organic Chemicals in Hanford Tanks: Historical Records . . . . . . . . . . . . 4

Organic Tank Fill History $\ldots \ldots \ldots \ldots \ldots \ldots \ldots \ldots \ldots \ldots \ldots \ldots \ldots \ldots \ldots \ldots$

Chemical Properties of Wastes in Organic Tanks $\ldots \ldots \ldots \ldots \ldots \ldots$

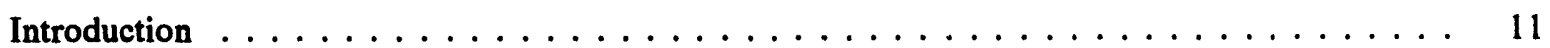

Oxidation of Organic Materials by Nitrate-Nitrite Mixtures $\ldots \ldots \ldots \ldots \ldots$

Formation of Flammable Organic Vapors $\ldots \ldots \ldots \ldots \ldots$

Potential Release of Volatile Organic(s) from Tank C-103 $\ldots \ldots \ldots \ldots \ldots$

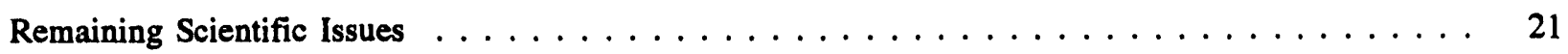

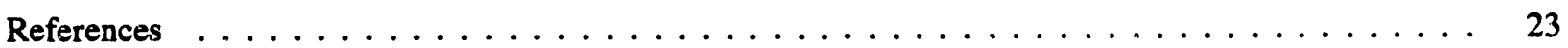

Appendix A Historical Perspectives of Wastes in Tank $241-C-103 \ldots \ldots \ldots \ldots \ldots \ldots$

Appendix B Tank C-103 Transaction History - Post $1976 \ldots \ldots \ldots \ldots \ldots \ldots \ldots$

Appendix C Tank 241-C-103 Vapor Constituents $\ldots \ldots \ldots \ldots \ldots \ldots \ldots \ldots \ldots \ldots$ 


\section{Tables}

2.1 Currently-Designated Organic Waste Tanks on Watch List $\ldots \ldots \ldots \ldots \ldots$

2.2 Organic Chemicals which May Have Been Introduced in Hanford Tanks $\ldots \ldots \ldots$

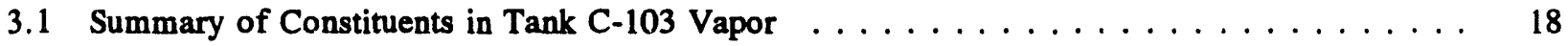

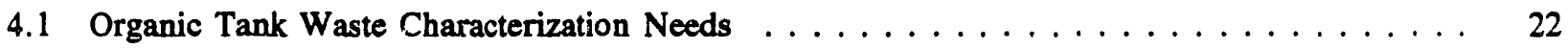




\section{Introduction}

Eight single-shell tanks (SSTs) at the U.S. Department of Energy Hanford Site contain various organic chemicals at concentrations estimated to be greater than $10 \mathrm{wt} \%$ sodium acetate equivalent (Hill and Babad 1991). Currently, these particular eight tanks, hereafter referred to as organic tanks, are included on a safety watch list along with tanks that contain ferrocyanide wastes or which periodically release or are suspected of releasing hydrogen gas.

Inclusion of the organic tanks on the safety watch list is justified for several reasons:

- Many of the organic chemicals are mixed with sodium nitrate and sodium nitrite oxidizing salts. Thus, the potential exists for a sufficient driving force, e.g., high temperature, to cause an exothermic reaction.

- The potential exists for liquid organic compounds present in one or more organic tanks to evaporate at rates high enough to produce a mixture of vapor and air that might ignite, given a source of ignition, and burn.

- Vapors of certain organic materials may potentially be released to tank farm environments and present health hazards to operating personnel.

Therefore, by the charter of the Tank Waste Science Panel, the organic tanks are properly included along with the ferrocyanide and hydrogen tanks in the purview of the Science Panel. This report has been prepared primarily for the benefit of the Science Panel to describe and discuss what little is currently known concerning the fill history and properties of wastes in the eight organic tanks. ${ }^{(a)}$ The extensive reference section provided lists all the known reports treating one or more aspects of the organic tanks and their contents.

(a) Similar reports have been prepared for the ferrocyanide tanks (Burger et al. 1991) and for the hydrogen tanks (Reynolds et al. 1991). 


\section{History of Organic Tanks}

\section{List of Organic Tanks}

Table 2.1 provides some relevant data concerning each of the eight organic tanks now on the watch list. One tank (241-C-103) is believed to contain a sizeable (e.g., hundreds to thousands of liters) inventory of PUREX process solvent, 30\% tributyl phosphate in NPH (Normal Paraffin Hydrocarbon), floating on the top of the aqueous waste in the tank (Borsheim and Kirch 1991). The other seven listed tanks are believed from historical data (Jungfleisch 1984; Schulz 1980) to contain or to have contained relatively large amounts of organic salts of citric acid, glycolic acid, EDTA (ethylenediaminetetraacetic acid), and HEDTA ( $\mathrm{N}$ hydroxy-ethylenediaminetriacetic acid) which might undergo deflagration reactions with $\mathrm{NaNO}_{3}$ or $\mathrm{NaNO}_{2}$. The organic content of the remaining 141 SSTs is known or believed to be less than $10 \mathrm{wt} \%$ sodium acetate equivalent. ${ }^{(a)}$ Wastes in these tanks are not expected, based on experimental data (Beitel 1976a; 1976b; 1976c; Fisher 1990), to deflagrate when mixed with $\mathrm{NaNO}_{3}$ or $\mathrm{NaNO}_{2}$ and strongly heated.

In all eight organic tanks the measured waste temperatures are in the range 16 to $46^{\circ} \mathrm{C}$. These temperatures are far below the 250 to $380^{\circ} \mathrm{C}$ demonstrated in laboratory tests with simulated organic$\mathrm{NaNO}_{3}$ mixtures to be necessary for onset of rapid exothermic reactions and initiation of deflagration.

The present selection (Table 2.1) of organic tanks on the safety watch list reflects a large measure of proper engineering conservatism. For example, three of the tanks (S-102, TX-118, and U-106) are included on the list on the basis of 1980 analyses of liquid waste in these tanks which indicated the presence of large concentrations of organic carbon. Very likely, by now some or all of these liquids have been transferred to double shell tanks. The actual amount of organic material currently associated with wastes in these tanks is unknown. Of the five remaining organic tanks on the watch list, four (B-103, SX-106, TX-105, and U-107) are included on the basis of computer code (Tracks Radioactive Component, Jungfleisch 1984) calculations which indicated that liquid containing large concentrations of carboxylates and aminopolycarboxylates were introduced into the tanks. Again, the actual amount of organic materials currently associated with wastes in these four tanks is unknown.

Some of the single shell tanks on the watch list have been interim stabilized, which means that all of the liquid that is possible to pump has been removed. This includes the intersticial liquor as well as the free liquid. However, as much as 114,000 liters (30,000 gallons) of interstitial liquid may remain. The solid material remaining has moisture associated with the solids as interstitial liquid or waters of hydration.

(a) Sodium acetate equivalent is a method of expressing the organic content of wastes that gives a bench mark against which to measure (judge) the potential of explosion relative to the Kyshtym accident (cf. Section 3.2.2). 
Table 2.1. Currently-Designated Organic Waste Tanks on Watch List

\begin{tabular}{|c|c|c|c|c|}
\hline Tank No. & $\begin{array}{c}\text { Organic Content } \\
\text { (wt\% Sodium Acetate } \\
\text { Equivalent) }{ }^{(\mathrm{a})} \\
\end{array}$ & $\begin{array}{c}\text { Content of } \\
\mathrm{NaNO}_{3} \text { and } \\
\underline{\mathrm{NaNO}}_{2} \text { wt\% (a) } \\
\end{array}$ & $\begin{array}{c}\text { Temperature }^{(b)} \\
{ }^{\circ} \mathrm{F} \\
\end{array}$ & Date Measured \\
\hline B-103 & $11.4^{(c)}$ & $60.5(c)$ & 61 & Feb. $11,1984^{(d)}$ \\
\hline$C-103^{(e)}$ & & & 120 & $(f)$ \\
\hline S-102 & $21.0^{(\mathrm{g})}$ & $41.0^{(\mathrm{g})}$ & 114 & July 3, 1989 \\
\hline SX-106 & $14.6^{(\mathrm{c})}$ & $80.9^{(c)}$ & 106 & July 3, 1989 \\
\hline TX-105 & $12.8^{(\mathrm{c})}$ & $52.7^{(\mathrm{c})}$ & 90 & Aug. $2,1985^{(\mathrm{d})}$ \\
\hline TX-118 & $20.2^{(\mathrm{g})}$ & $50.4^{(g)}$ & 91 & July 3, 1989 \\
\hline U-106 & $46.6^{(g)}$ & $52.4^{(\mathrm{g})}$ & 80 & July 3,1989 \\
\hline U-107 & $14.7^{(\mathrm{c})}$ & $75.4^{(\mathrm{c})}$ & 76 & July 3,1989 \\
\hline
\end{tabular}

(a) Calculated and reported by Fisher (1990).

(b) From Hanlon (1989) except for C-103.

(c) Calculated from data developed by TRAC (Tracks Radioactive Components) computer code (Jungfleish 1984).

(d) Failed thermocouple trees in cool tanks are not replaced; data taken as long as possible.

(e) There is strong evidence that a separate layer of tributyl phosphate-diluent exists in this tank.

(f) From Borsheim and Kirch (1991).

(g) Calculated from data in Schulz (1980); all or part of liquid from which composition data were derived may have been transferred to a double shell tank.

It should be noted here that the double shell tanks are not on the watch list although the total organic carbon content of the waste approaches $10 \mathrm{wt} \%$ in some of these tanks and is above $3 \mathrm{wt} \%$ in most. These tanks contain "double shell slurry," "complexant concentrate," and "double shell slurry feed." While the total organic carbon values exceed those values that caused the single shell tanks to be placed on the watch list, it is generally agreed that there is sufficient liquid present to obviate any safety issue.

However, it might be useful to revisit this decision in the light of the new information gathered from the single shell tank waste studies. Discussion of the double shell tanks is outside the scope of this document.

\section{Organic Chemicals in Hanford Tanks: Historical Records}

M. J. Klem (1990) published a comprehensive listing of all the chemicals used at the Hanford site in the period 1944-1980. Klem compiled this list from historical chemical flowsheets, purchase records, and other records of chemicals used during almost four decades in separations plants, analytical laboratories, 
equipment decontamination facilities, and other facilities at the Hanford Site. Table 2.2 in this report, which lists all the organic materials used at the Hanford Site in the period 1944 to 1980, is abstracted from Klem's report.

In most cases identification of a particular chemical used at the Hanford site as an organic material is certain. In a few cases, noted in Table 2.2, identification is not so certain. Klem points out that, although it is probable, there is no guarantee that all of the organic materials listed in Table 2.2 found their way into Hanford underground waste tanks. Also, as Klem points out, many, if not all, of the organic compounds listed in Table 2.2 underwent radiolytic and/or chemical degradation to other compounds. And, of course, those compounds with high vapor pressures, e.g., $\mathrm{CCl}_{4}$, methylisobutyl ketone, etc., likely evaporated if and when placed in thermally hot waste tanks.

Klem does not provide estimates of the amounts of the various organic chemicals purchased and used at the Hanford site other than to note that some were used in bench-scale activities while others were used routinely in plant-scale operations. Allen (1976) calculates that $3.3 \times 10^{6}, 9.0 \div 10^{6} .2 .7 \times 10^{6}$, and $6.6 \times$ $10^{6} \mathrm{~g}$ moles, respectively, of citrate, glycolate, hydroxyethylenediamine-triacetate, and ethylenediaminetetraacetate were added to some Hanford SSTs.

\section{Organic Tank Fill History}

A brief summary of historical information concerning the types of wastes introduced into each of the organic tanks is presented in this section. More detailed information about the fill history of Tank C-103 is provided in Appendices A and B. Reports by Jungfleisch (1984) and Fisher (1990) should be consulted for details of the fill history of the other seven organic tanks.

Tank B-103. Tank B-103 ( $2 \times 10^{6} \mathrm{~L}$ capacity) was constructed in 1944 and originally used to contain neutralized Bismuth Phosphate process waste. Thereafter, it was used to contain various process wastes. In 1977, for a short time, it was part of the 242 A Vacuum Evaporator bottoms tank system. No new wastes were placed in Tank B-103 after 1977, and in 1979 it was classified as a tank of questionable integrity. This tank has been interim stabilized (liquid pumped from it) and isolated (pipes into and out of the tank have been capped) (Hanlon 1989).

Tank C-103. Tank C-103 ( $2 \times 10^{6} \mathrm{~L}$ capacity) was first filled in 1946. From about 1977 on, Tank C-103 received wastes from other $C$ farm tanks and transferred those wastes out of the farm. Appendix A provides an account of transfer of various wastes into and out of Tank C-103. Tank C-103 is particularly noteworthy since it is, as far as is known, the only SST which contains, apparently, a layer of organic solvent floating on top of aqueous wastes in the tank (Appendix B). Tank C-103 was deactivated in 1979. 
Table 2.2. Organic Chemicals which May Have Been Introduced in Hanford Tanks ${ }^{(a)}$

Compound or Trade Name

Acetic Acid

Acetone

Alizarin Yellow

(Dihroxyanthraquinone)

Amberlite XE-270

Ammonium Acetate

Ammonium Oxalate

Benzene

bis-2-ethylhexyl phosphoric acid

Bromcresol Purple

Bromonapthalene

Butanol

Carbon Tetrachloride

Citric Acid

Di-2-ethylhexylphosphoric

Acid

Dibutylbutylphosphonate

Dibutylphosphoric Acid

Diethylenetriaminepentaacetic

Acid

Diversy Chemical $159^{(b)}$

Dodecane

Dowex 21K

Dowex 50

Duolite ARC-359 Resin

Ethanol

Ethyl Ether

Ethylene Glycol

Formaldehyde

Glycolic Acid
Empirical Formula or Composition

Source

$$
\begin{aligned}
& \mathrm{CH}_{3} \mathrm{COOH} \\
& \mathrm{CH}_{3} \mathrm{COCH}_{3} \\
& \mathrm{C}_{14} \mathrm{H}_{4} \mathrm{HO}_{4}
\end{aligned}
$$

Cation Exchanger Resin

$\mathrm{NH}_{4} \mathrm{OOCCH}_{3}$

$\left(\mathrm{NH}_{4}\right)_{2} \mathrm{C}_{2} \mathrm{O}_{4}$

$\mathrm{C}_{6} \mathrm{H}_{6}$

$\left(\mathrm{C}_{8} \mathrm{H}_{17} \mathrm{O}_{2}\right) \mathrm{POOH}$

$\mathrm{C}_{7} \mathrm{H}_{6} \mathrm{OHBr}$

$\mathrm{C}_{10} \mathrm{H}_{7} \mathrm{Br}$

$\mathrm{C}_{4} \mathrm{H}_{9} \mathrm{OH}$

$\mathrm{CCl}_{4}$

$\mathrm{C}_{3} \mathrm{H}_{4} \mathrm{OH}(\mathrm{COOH})_{3}$

$\mathrm{C}_{16} \mathrm{H}_{23} \mathrm{O}_{10} \mathrm{~N}_{3}$

$\left(\mathrm{C}_{4} \mathrm{H}_{9} \mathrm{O}\right)_{2} \mathrm{C}_{4} \mathrm{H}_{9} \mathrm{PO}$

$\left(\mathrm{C}_{4} \mathrm{H}_{9} \mathrm{O}_{2}\right) \mathrm{POOH}$

$\mathrm{C}_{16} \mathrm{H}_{35} \mathrm{O}_{4} \mathrm{P}$

Unknown

$\mathrm{C}_{12} \mathrm{H}_{25}$

Anion Exchanger Resin

Cation Exchanger Resin

Sulfonated Phenolic

$\mathrm{C}_{2} \mathrm{H}_{5} \mathrm{OH}$

$\mathrm{C}_{2} \mathrm{H}_{5} \mathrm{OC}_{2} \mathrm{H}_{5}$

$\mathrm{HOC}_{2} \mathrm{H}_{4} \mathrm{OH}$

$\mathrm{HCHO}$

$\mathrm{HOCH}_{2} \mathrm{COOH}$
Rohm \& Haas Co.

\section{Unknown}

Dow Chemical Co.

Dow Chemical Co.

Diamond Shamrock Co. 
Table 2.2. (contd)

Compound or Trade Name

Glycerol

Hydroxyquinoline

Immunuol 1468-2 (b)

Ionac A-580 Resin

Isoamyl Acetate

Isopropyl Alcohol

Jasco Paint Stripper

Kelite $25 E^{(b)}$

Keraff $^{(b)}$

Kerosene

Mandelic Acid

Methanol

Methylethyl Ketone

Methylisobutyl Ketone

Methyllactic Acid

Mineral Oil

Morpholine

Naphthylamine

Nitrilotriacetic Acid (NTA)

Normal Paraffin Hydrocarbon

Oakite Clear Guard ${ }^{(b)}$

Oakite Rust Stripper ${ }^{(b)}$

Oakite Swiff(b)

Orthophenantroline

Orvus $\mathbf{K}^{(\mathbf{b})}$

Oxalic Acid

Pace-S-Teen ${ }^{(b)}$

Penvert $192^{(b)}$

Permutit SK Resin

Pentasodiumdiethylenetriaminepentaacetate

Empirical Formula or Composition

Source

$\mathrm{CH}_{2} \mathrm{OHCHOHCH}{ }_{2} \mathrm{OH}$

$\mathrm{C}_{9} \mathrm{H}_{6} \mathrm{NOH}$

Unknown

Polyvinylpuridine with methyl groups

$\mathrm{C}_{4} \mathrm{H}_{8}\left(\mathrm{CH}_{3}\right) \mathrm{COOCH}_{3}$

$\mathrm{C}_{3} \mathrm{H}_{7} \mathrm{OH}$

Methylene chloride, $\mathrm{CH}_{3} \mathrm{OH}$

Unknown

Unknown

$\mathrm{C}_{10} \mathrm{H}_{22}$ to $\mathrm{C}_{16} \mathrm{H}_{34}$

$\mathrm{C}_{6} \mathrm{H}_{5} \mathrm{CHOHCOOH}$

$\mathrm{CH}_{3} \mathrm{OH}$

$\mathrm{CH}_{3} \mathrm{COC}_{2 \mathrm{H}^{5}}$

$\mathrm{CH}_{3} \mathrm{COC}_{4} \mathrm{H}_{9}$

$\mathrm{CH}_{3} \mathrm{CH}(\mathrm{OH}) \mathrm{COOCH}_{3}$

Light Hydrocarbons

$\mathrm{C}_{4} \mathrm{H}_{9} \mathrm{NO}$

$\mathrm{C}_{10} \mathrm{H}_{9} \mathrm{~N}$

$\mathrm{N}\left(\mathrm{CH}_{2} \mathrm{COOH}\right)_{3}$

$\mathrm{C}_{10} \mathrm{H}_{22}$ to $\mathrm{C}_{14} \mathrm{H}_{30}$

Unknown

Unknown

Unknown

$\mathrm{C}_{12} \mathrm{H}_{8} \mathrm{~N}_{2}$

Unknown

$\mathrm{H}_{2} \mathrm{C}_{2} \mathrm{O}_{4}$

Unknown

Unknown

Polyvinylpuridine with methyl groups

$\mathrm{N}_{3}\left(\mathrm{C}_{2} \mathrm{H}_{2}\right)_{2}(\mathrm{COONa})_{5}$
Harry Miller Corp.

Ionac Chemical Corp.

Jasco Chem. Co.

Kelite Corp.

Unknown
Oakite Products Inc. Oakite Products Inc.

Oakite Products Inc.

Proctor and Gamble

Unknown

Unknown

Ionac Chem. Co. 
Table 2.2. (contd)

Compound or Trade Name

Perokleen $^{(b)}$

Resin IRN-150

Saf-Tee Solvent FO-128(b)

Saniflush

S-diphenylcarbazide

Shell E-2342

Shell Spray Base

Sodium Acetate

Sodium Gluconate

Sodium Oxalate

Sodium Tartrate

Soltrol-170

Sparton DC $13^{(\mathrm{b})}$

Sugar

Tartaric Acid

Tetrabromoethane

Tetrasodium ethylenediaminetetraacetate

Tetraphenylboron

Thenoyltrifluoroacetone

Thymolphthalein

Toluene

Tributyl Phosphate

Trichloroethane

Tri-n-dodecylamine

Tris-iso-octylamine

Tri-n-octylamine

Tris(hydroxymethyl)aminomethane

Trisodium hydroxyethylenediaminetriacetate

Turco Alkaline Rust Remover
Empirical Formula or Composition

Unknown

Unknown

Styrene Divinyl Benzene

Unknown

Oxalic acid, diethylurea, alkyltrimethyl-ammonium chloride $\left(\mathrm{C}_{6} \mathrm{H}_{5} \mathrm{NH} . \mathrm{HN}\right)_{2} \mathrm{CO}$

Naphthalene and

$\mathrm{C}_{10} \mathrm{H}_{22}$ to $\mathrm{C}_{16} \mathrm{H}_{34}$

$\mathrm{NaOOCCH}_{3}$

$(\mathrm{CHOH})_{4} \mathrm{CO}_{2} \mathrm{HCH}_{2} \mathrm{ONa}$

$\mathrm{Na}_{2} \mathrm{C}_{2} \mathrm{O}_{4}$

$\mathrm{Na}_{2} \mathrm{C}_{2} \mathrm{H}_{4} \mathrm{O}_{6}$

$\mathrm{C}_{10} \mathrm{H}_{22}$ to $\mathrm{C}_{16} \mathrm{H}_{334}$

Unknown

$\mathrm{C}_{12} \mathrm{H}_{22} \mathrm{O}_{11}$

$\mathrm{C}_{2} \mathrm{H}_{2}(\mathrm{OHCOOH})_{2}$

$\left(\mathrm{CHBr}_{2}\right)_{6}$

$\mathrm{N}_{2} \mathrm{C}_{2} \mathrm{H}_{4}\left(\mathrm{C}_{2} \mathrm{H}_{2} \mathrm{O}_{2}\right) \mathrm{Na}_{4}$

$\left(\mathrm{C}_{6} \mathrm{H}_{5}\right)_{4} \mathrm{~B}$

$(\mathrm{CH})_{3} \mathrm{SOCH}_{3} \mathrm{CODF}_{3}$

$\mathrm{C}_{28} \mathrm{H}_{30} \mathrm{O}_{4}$

$\mathrm{C}_{6} \mathrm{H}_{5} \mathrm{CH}_{3}$

$\left(\mathrm{C}_{4} \mathrm{H}_{9} \mathrm{O}\right)_{3} \mathrm{PO}$

$\mathrm{CH}_{3} \mathrm{CCl}_{3}$

$\left[\mathrm{CH}_{3}\left(\mathrm{CH}_{2}\right)_{11}\right]_{33} \mathrm{~N}$

$\left[\left(\mathrm{CH}_{3}\right)_{2} \mathrm{CH}\left(\mathrm{CH}_{2}\right)_{5}\right]_{3} \mathrm{~N}$

$\left[\mathrm{CH}_{3}\left(\mathrm{CH}_{2}\right)_{7}\right]_{3} \mathrm{~N}$

$\left(\mathrm{CH}_{2} \mathrm{OH}\right)_{3} \mathrm{CNH}_{2}$

$\mathrm{N}_{2} \mathrm{C}_{2} \mathrm{H}_{4}\left(\mathrm{C}_{2} \mathrm{H}_{2} \mathrm{O}_{2} \mathrm{Na}\right)_{3}\left(\mathrm{C}_{2} \mathrm{H}_{4} \mathrm{OH}\right)$

Kerosene and $\mathrm{NaOH}$
Source

Unknown

Boyle Midway Inc.

Shell Oil Co.

Shell Oil Co.

Phillips Chemical Co.

Unknown 
Table 2.2. (contd)

Compound or Trade Name

Turco Deseal Zit2

Turco EPO Strip ${ }^{(b)}$

Turco EPO Strip NP(b)

Turco Fabrifilm

Turco Plaudit ${ }^{(b)}$

Turco 2822

Turco $2844^{(b)}$

Turco 4358-4A ${ }^{(b)}$

Turco 4501A

Turco 4518

Turco 4521

Turco 4605-8(b)

Turco $4669^{(b)}$

Turco $4715^{(b)}$

Turco 4738 (Thin) $^{(\mathbf{b})}$

Turco T-5561

Turco T-5589

Urea

West Loade Degreaser ${ }^{(b)}$

Wyandotte Kelvar ${ }^{(\mathbf{b})}$

Wyandotte MF $^{(b)}$

Wyandotte P1075(b)

Wyandotte $1112^{(b)}$

Xylene

\section{Empirical Formula or} Composition

Methylene chloride, Acetic Acid

Unknown

Unknown

Toluene, Butanol Isopropanol, Acetone

Unknown

Methylene chloride, Acetic Acid

Unknown

Unkain ar.

Hydruxy:ili: aines

Sodium dodecylbenzene-sulfonate, Oxalic Acid,

Ammonium oxalate, Oxalic Acid, Sodium dodecylbenzenesulfonate

Unknown

Unkuown

Unknown

Unknown

2-Butoxyethanol, Dioctylphthalate, Morpholine, and Mineral Oil

Isopropanol, $\mathrm{NaOH}$

$\mathrm{CO}\left(\mathrm{NH}_{2}\right)_{2}$

Unknown

Unknown

Unknown

Unkwown

Unknown

$\left(\mathrm{C}_{6} \mathrm{H}_{4}\right)\left(\mathrm{CH}_{2}\right)_{2}$
Source

(c)

(c)

(c)

(c)

(c)

(c)

(c)

(c)

(c)

(c)

(c)

(c)

(c)

(c)

(c)

(c)

(c)

West Chemical Products

(d)

(d)

(d)

(d)

(a) Data abstracted from Klem (1990)

(b) Assumed to contain organic materials

(c) Product of Turco Products, Inc.

(d) Product of Wyandotte Chemical Products 
Tank S-102. Tank S-102 (2.8 $\times 10^{6} \mathrm{~L}$ capacity) wa. irst used in 1953 and continued in active service until 1980. From 1953 to 1973 Tank S-102 received and stored REDOX process wastes. Tank S-102 was used as the feed tank for the 242-S Vacuum Evaporator from 1973 to 1977 . At least $4.5 \mathrm{x}$ $10^{8} \mathrm{~L}$ of wastes were transferred through Tank S-102 in the period 1973 to 1977 . From 1977 to 1980 Tank S-102 was part of the 242-S Vacuum Evaporator bottoms tanks system and routinely received evaporator bottoms. The most likely source of organic materials in Tank S-102 are the REDOX process wastes and 242-S Evaporator feeds containing organic complexants.

Tank SX-106. Tank SX-106 $\left(3.8 \times 10^{6} \mathrm{~L}\right.$ capacity) was placed in service to receive wastes from operation of the REDOX process. In 1974, Tank SX-106 became part of the 242-S Vacuum Evaporator bottoms system and received waste from the evaporator; other tanks also staged waste in Tank SX-106 as part of the 242-S Evapo ator system. The most likely source of organic waste in Tank SX-106 was complexant concentrate waste stored in the tank in 1978 and 1979. Tank SX-106 was taken out of service in 1980.

Tank TX-105. Tank TX-105 $\left(2.8 \times 10^{6} \mathrm{~L}\right.$ capacity) was placed in service in 1952 and stored REDOX process an: Metal Recovery Process wastes from 1952 to 1971. In 1971, Tank TX-105 became part of the 242-T Evaporator bottoms tanks system and received waste from the evaporator and recycled waste back into the evaporator feed syetem. In 1972 use of Tank TX-105 was restricted, and in 1978 Tank TX-105 was declared to be of questionabie integrity and was taken out of service. Organic materials were most likely introduced into Tank TX-105 while it was used as past of the 242-T Evaporator bottoms ak system. This tank has been interim stabilized and isolated (Hanlon 1989).

Tank TX-118. Tank TX-118 came on line in 1952 as a feed tank for the 242-T Evaporator. From 1952 through 1956 over $3.4 \times 10^{6} \mathrm{~L}$ of various wastes passed through Tank TX-118. From 1956 until 1965, when the 242-T Evaporator was restarted, various types of waste were stored in Tank TX-118. Tank TX-118 again served as a feed tank for the 242-T Evaporator; during that time more than $9.1 \times 10^{7}$ L of waste passed through the tank. From 1976 until it was removed from service in 1980, Tank TX-118 was part of the 242-T Evaporator bottoms tank system. This tank has been interim stabilized and isolated (Hanlon 1989).

Tank U-106. Tank U-106 $\left(2.0 \times 10^{6} \mathrm{~L}\right.$ capacity) came on line in 1948 and remained in active service until 1978 when it was declared to be of questionable integrity. Tank U-106 contained REDOX process waste from about 1951 until 1976 when the 242-S Vacuum Evaporator started up. Tank U-106 served as part of the 242-S Evaporator bottoms tank system. From 1978 to 1980 Tank U-106 contained complexant concentrate, the most probable source of organic chemicals in the tank.

Tank U-107. Tank U-107 (2.0 × $10^{6} \mathrm{~L}$ capacity) was first used in 1948. From 1948 until 1972 it was used to store various process waste solutions. From 1972 until 1976 Tank U-107 was a designated receiver of "customer" wastes shipped from various Hanford site contractors in the 100 and 300 Areas to the 200 Areas. From 1976 until 1980 Tank U-107 was used as an evaporator bottoms tank and also to store complexant concentrate waste. 


\section{Chemical Properties of Wastes in Organic Tanks}

\section{Introduction}

Compared to our knowledge of the chemical properties of wastes in the ferrocyanide and hydrogen tanks, the chemical properties of wastes in the organic tanks are relatively unknown. Indeed, as Hill ant Babad (1991) note, "work on this issue is just beginning." The remaining parts of this section summatin results of the small amount of experimental work and also of the several paper assessments and evaluations of the hazards associated with wastes in organic tanks.

\section{Oxidation of Organic Materials by Nitrate-Nitrite Mixtures}

\section{Experimental Investigations}

Beitel (1976a; 1976b; 1976c; 1977) in the period 1975-1977 conducted various laboratory studies to investigate oxidative reaction of several candidate organic materials with $\mathrm{NaNO}_{3}$. Beitel's initial studies (Beitel 1976a; 1976b) were performed to test for self-supporting combustion. These experiments utilized 1-g mixtures of organic materials and $\mathrm{NaNO}_{3}$ or, in some cases, simulated solid salt cake. Organic test materials included charcoal, paraffin oil, paraffin wax, and Dowex 21-K (Dow Chemical Co.) and Permutit SK (Permutit Co.) anion exchange resins. ${ }^{\text {(a) }}$ Organic-nitrate mixtures were packed with a known combustible mixture of charcoal and $\mathrm{NaNO}_{3}$ that was ignited by means of a small heated nichrome wire.

Beitel observed that organic materials with a high boiling point (low vapor pressure) reacted vigorously and explosively if the $\mathrm{NaNO}_{3}$-organic mixture contained between 10 and 30 wt\% organic material. High vapor pressure materials (e.g., hydrocarbon fuels vaporized and burned above the solid salt cake, but would not react with the $\mathrm{NaNO}_{3}$. In all cases, ignition temperatures were observed to be $>400^{\circ} \mathrm{C}$.

Beitel's experiments were later repeated and extended by Putnam (1977) at the Hazards Research Corporation in Denville, New Jersey. These latter tests were designed to investigate the reactivity of simulated salt cake containing $95 \mathrm{wt} \% \mathrm{NaNO}_{3}$ with Dowex $21 \mathrm{~K}$ resin or kerosene, or an aqueous solution containing $0.54 \mathrm{M} \mathrm{Na}$ HEDTA and $0.27 \mathrm{M} \mathrm{Na}_{4}$ EDTA. From 20 to $160 \mathrm{~g}$ of salt cake-organic material mixtures, containing 1 to 14 wh organic material, were placed in thick-walled stainless steel reactors capable of withstanding the knazimum pressure that could result from any decomposition reactions. Reaction mixtures were heated to $250^{\circ} \mathrm{C}$, a temperature limitation imposed by the heat exchanger media (oil), at a rate of $10^{\circ} \mathrm{C}$ per minute. Additionally, a fresh salt cake-organic material sample was heated at

(a) This selection of test organic materials, made in 1976, reflected what was known then concerning organic materials that had been introduced into some SSTs. 
$250^{\circ} \mathrm{C}$ for $24 \mathrm{~h}$. Beitel (1977) states, "The larger mass $(160 \mathrm{~g})$ and the sealed container made the tests more severe and more closely simulated the expected behavior of a large (thousands of $\mathrm{kg}$ ) mass and/or a deflagration once initiated."

All pressurized tests were negative. (Emphasis supplied). This result is consistent with Beitel's prior observation that mixtures of $\mathrm{NaNO}_{3}$ and organic test materials were unreactive at temperatures below $250^{\circ} \mathrm{C}$.

Putnam (1977) also heated a mixture of simulated salt cake and Dowex-21K resin in an open container; ignition consistently occurred at $450^{\circ} \mathrm{C}$. When kerosene was heated in an open container, the kerosene evaporated at temperatures below $400^{\circ} \mathrm{C}$ without reaction with the salt cake. Kerosene was also added to salt cake and heated over an open flame; at the flash point of kerosene, the vapors ignited and burned while the salt cake remained at temperatures below about $175^{\circ} \mathrm{C}$ and did not participate in the reaction other than to serve as a wick.

From the results obtained by ligzards Research Corp. personnel, Beitel drew the following conclusions:

- Sodium nitrate-based salt cakes containing organic materials are stable against deflagration at temperatures below $250^{\circ} \mathrm{C}$.

- Sodium nitrate-based salt cakes will ignite and react explosively with most organic materials that are still liquid or solid at temperatures in the range 380 to $450^{\circ} \mathrm{C}$.

- If a volatile hydrocarbon is added to a sodium nitrate-based salt cake and subsequently heated slowly and uniformly, the hydrocarbon will evaporate before ignition temperatures $\left(\sim 400^{\circ} \mathrm{C}\right)$ are reached.

- If a volatile hydrocarbon is added to a sodium nitrate-based salt cake and subsequently ignited, the hydrocarbon will flame above the salt cake, reacting with environmental gaseous oxygen. The salt cake will act as a wick, transporting the hydrocarbon to the surface by capillary action, and evaporation will cool the salt cake to below ignition temperature."

After evaluation of all experimental data, Beitel (1976) also concluded:

- Organic materials added to Hanford SSTs were not nitrated at the time of addition and cannot have been subsequently transformed to detonatable nitrated organics.

- Even if a combustible concentration of organic materials existed in a SST, it could not be ignited because temperaiures generated by radionuclide decay in the salt cake are below $175^{\circ} \mathrm{C}$.

- The many years during which the liquid high level waste tanks were boiling, and the subsequent evaporation-crystallization processing, have allowed many of the more volatile organics to be distilled off, further reducing maximum expected concentrations of organics. 
- Furthermore, even if any of the major organic solvents were present in concentrations theoretically adequate to support combustion, they probably would not burn. Because of their high volatility, such solvents are more difficult to react than charcoal, the normal fuel in $\mathrm{NaNO}_{3}$-based explosives, and may be impossible to ignite.

\section{Relevancy of the Kyshtym Explosion}

\section{Background Information}

A waste tank at the former USSR Kyshtym industrial complex in the Southern Urals exploded on September 29, 1957 (TASS 1989; Nikipelov et al. 1989). The tank was filled with highly radioactive waste containing about $100 \mathrm{~g} / \mathrm{L} \mathrm{NaNO}_{3}$ and about 60 to $80 \mathrm{~g} / \mathrm{L}$ of sodium acetate. Official release of the incident in 1989 by the Russians confirmed much previous speculation by Medvedev (1977) and others (Parker 1978; Soran and Stillman 1982). The explosion occurred in the steel lined concrete vault foliowing failure of a cooling system.

\section{Potential Organic Salts in Hanford SSTs}

The 1989 release of information about the $\mathrm{NaNO}_{3}$-sodium acetate explosion also prompted a detailed study (Fisher 1990) to assess the existence or likelihood of the existence of potentially explosive mixtures of acetates or similar substances in admixture with $\mathrm{NaNO}_{3}$ and/or $\mathrm{NaNO}_{2}$ in Hanford SSTs. Of particular and immediate concern were those SSTs into which were introduced B plant alkaline wastes containing sodium salts of citric acid, glycolic acid, HEDTA, and EDTA. Amounts of these materials added to Hanford SSTs were, according to Allen (1976), $3.3 \times 10^{6}, 9.0 \times 10^{6}, 2.7 \times 10^{6}$, and $6.6 \times 10^{6} \mathrm{~g}$ moles, respectively. The quantities of these particular four organic compounds far surpass the total amount of all other organic salts added to the Hanford SSTs.

The carboxylates and aminopolycarboxylates added to Hanford SSTs are all aqueous-soluble organic salts. They can all be considered acetates or modified acetate groups and, according to Fisher (1990), are expected to provide "fuel" values in deflagration reactions much as sodium acetate does. Minor amount of other organic salts provide fuel values similar to the carboxylates and aminopolycarboxylates.

From an analysis of historical data, Fisher (1990) was able to identify seven SSTs (cf. Table 2.1) that appear likely to contain enough organic salts to form potentially explosive mixtures with $\mathrm{NaNO}_{3}$ and/or $\mathrm{NaNO}_{2}$. The historical data derive from three sources: 1) the TRAC computer code (Jungfleisch 1984); 2) 15 chemical assays of samples taken from one or more risers in 18 SSTs; and 3) data reported by Schulz (1980) for waste liquors taken from some SSTs. ${ }^{(a)}$

(a) A complete set of pertinent historical data is provided in the appendices to the Fisher report, because of the ready availability of the Fisher report, these data are not included here. The appendices to the Fisher report also indicate the methodology used to convert total organic carbon analyses to "sodium acetate equivalent." 
The TRAC code was developed to estimate the radionuclide content of each SST from a knowledge of the calculated (Oak Ridge Isotope Generation--ORIGIN--computer code) amount of radionuclides in the irradiated fuel processed at Hanford and from historical records of transfers into and out of each SST. Quantities of various nonradioactive chemicals, including some organic materials introduced into each of the SSTs, are also estimated by the TRAC code.

In 1989-1990, when Fisher analyzed his iorical data, only 18 of the SSTs had been sampled and chemically analyzed. None of the tanks sampled corresponded to those identified by the TRAC code as containing significant amounts of organic salts. And, none of the 18 tanks actually contained appreciable amounts of organic carbon.

Liquid wastes in Tanks S-102, TX-118, and U-106 were found by Schulz (1980) in 1980 to contain high concentrations of organic carbon. The organic carbon content of the solids in tanks was not determined. Furthermore, some or all of the liquid present in these tanks in 1980 has very likely by now been transferred to double-shell tanks. Even so, for conservatism these three tanks are still placed on the organic tank watch list.

\section{Experimental Studies of Deflagration of $\mathrm{NaNO}_{3}-\mathrm{NaNO}_{2}$-Sodium Acetate Mixtures}

In an appendix to his reprit, Fisher also briefly described results of bench-scale tests conducted to study the deflagration of mixtures of $\mathrm{NaNO}_{3}-\mathrm{NaNO}_{2}$-sodium acetate. Fisher states, "Mixtures of sodium acetate with varying amounts of $\mathrm{NaNO}_{3}, \mathrm{NaNO}_{2}$, and equal amounts of $\mathrm{Na}_{2} \mathrm{CO}_{3}, \mathrm{Na}_{2} \mathrm{SiO}_{3}$, and $\mathrm{NaAl}(\mathrm{OH})_{4}$, each placed on aluminum $\mathrm{Nil}$ or tightly wrapped in aluminum foil, were heated to estimate the lower explosion limit for bare an , 7a ially-contained mixtures. It appeared that any composition containing more than about $10 \mathrm{wt} \%$ sodiwis acetate and about $20 \mathrm{wt} \% \mathrm{NaNO}_{3}$ or $\mathrm{NaNO}_{3}-\mathrm{NaNO}_{2}$ underwent deflagration when strongly heated, although compositions containing less than about 20 wt\% combined oxidant were not tested."

\section{SST Temperatures}

Fisher cites data (cf. Table 2.1) which show that the measured temperature of wastes in seven of the organic tanks are in the range 16 to $46^{\circ} \mathrm{C}$. These temperatures are well below those, e.g., 260 to $380^{\circ} \mathrm{C}$ required (Beitel 1976a; 1976b; 1976c) for onset of rapid exothermic reactions and deflagration of mixtures of $\mathrm{NaNO}_{3}$ and $\mathrm{NaNO}_{2}$ and organic salts or, for that matter, of mixtures and $\mathrm{NaNO}_{3}$ and ferrocyanide compounds (Burger and Scheele 1988). Thus, as Fisher notes, mixtures of organic carboxylates and aminopolycarboxylates and other organic salts with $\mathrm{NaNO}_{3}$ and/or $\mathrm{NaNO}_{2}$ in Hanford SSTs, although some may consist of potentially explosive composition, are safe since they cannot explode unless sufficiently heated.

\section{Non-Relevancy of Red Oil-Initiated Deflagrations}

Fisher (1990) and Borshiem and Kirch (1991) also conclude that red oil is not a credible agent for initiating deflagration of organic salt- $\mathrm{NaNO}_{3}-\mathrm{NaNO}_{2}$ mixtures in SSTs. So-called red oil is a complex, dense mixture of organic compounds formed as the result of hydrolytic and other reactions between certain 
heated TBP-diluent solutions and aqueous metal nitrate solutions (Shoun and Thompson 1984). The presence in the organic phase of TBP complexes of $\mathrm{UO}_{2}\left(\mathrm{NO}_{3}\right)_{2}, \mathrm{Pu}\left(\mathrm{NO}_{3}\right)_{4}$, or $\mathrm{Th}\left(\mathrm{NO}_{3}\right)_{4}$ is apparently essential to red oil formation. Red oil contains volatile organic compounds which ignite at temperatures in the range 130 to $150^{\circ} \mathrm{C}$ depending upon the diluent. Explosions and fires are readily possible when the rate at which metal nitrate-TBP and $\mathrm{HNO}_{3}$-TBP species decompose is rapid enough to generate flammable concentrations of reaction products.

Fisher notes that even if red oil had been introduced into one or more SST it would quickly and quietly decompose upon contact with alkaline waste solutions. The heavy metals would precipitate as uranates or hydroxides, releasing the TBP fraction.

\section{Ammonium Nitrate-Initiated Deflagration of Organic Salts}

Fisher (1990) and Borshiem and Kirch (1991) also discount the likelihood of deflagration of a mixture of $\mathrm{NaNO}_{3}$-organic salts or $\mathrm{NaNO}_{2}$-organic salts initiated by self heating of $\mathrm{NH}_{4} \mathrm{NO}_{3}$. In alkaline solutions, $\mathrm{NH}_{4} \mathrm{NO}_{3}$ reacts to form $\mathrm{NH}_{3}$ (Reaction 1):

$$
\mathrm{NH}_{4} \mathrm{NO}_{3}+\mathrm{OH}^{-}=\mathrm{NH}_{3}+\mathrm{H}_{2} \mathrm{O}+\mathrm{NO}_{3}^{-}
$$

But, as Fisher mentions, $\mathrm{NH}_{4} \mathrm{NO}_{3}$ has been observed in tank vent headers; these deposits of $\mathrm{NH}_{4} \mathrm{NO}_{3}$ result from reaction of $\mathrm{NH}_{3}$ and $\mathrm{NO}_{2}$ according to Reaction 2:

$$
2 \mathrm{NH}_{3}+2 \mathrm{NO}_{2}=\mathrm{N}_{2} \mathrm{O}+\mathrm{H}_{2} \mathrm{O}+\mathrm{NH}_{4} \mathrm{NO}_{3}
$$

Ammonium nitrate is a well-known explosive and is used as a base for rocket fuel as well as for industrial explosives (Kirch 1982). Ammonium nitrate is very stable at ambient temperatures and is relatively insensitive to impact and friction (Kirch 1983) and requires a strong initiator to detonate, particularly if pure. Confinement (Hainer 1955) is required to maintain the products of endothermic decomposition $\left(\mathrm{NH}_{3}\right.$ and $\mathrm{HNO}_{3}$ ) and to raise reaction temperature until exothermic decomposition to $\mathrm{N}_{2} \mathrm{O}$ and $\mathrm{H}_{2} \mathrm{O}$ becomes a runaway thermal excursion. Without confinement, the combination of endothermic and exothermic reaction processes results in self limiting temperatures in the range 200 to $350^{\circ} \mathrm{C}$. Fisher concludes that $\mathrm{NH}_{4} \mathrm{NO}_{3}$ in vent headers or as "snow" on tank walls cannot spontaneously explode if it is unconfined and therefore cannot lead to deflagration of organic salt- $\mathrm{NaNO}_{3}$ mixtures. 


\section{Formation of Flammable Organic Vapors}

\section{Introduction}

Only for Tank 241-C-103, in which there is very likely a separate layer of PUREX plant TBP-NPH solvent at the top of the aqueous waste in the tank, is there concern about the potential formation of flammable organic vapors in the tank head space. Borsheim and Kirch (1991) recently assessed the potential formation of flammable organic vapors in Tank C-103 based on data available as of about August 1989. They note that any volatile solvents, e.g., methylisobutyl ketone, kerosene, etc. introduced into Hanford SSTs in the period 1950 to 1970 evaporated when the contents of the tank were concentrated in evaporator-crystallizer units.

The inventory of TBP-NPH solvent in Tank C-103 most likely originated as a transfer from Tank C-102 in 1975. An engineering study (Hall 1972) performed in 1972 identified the presence of about 136,000 L of TBP-NPH solvent in Tank C-102. Tank C-102 was partially isolated in 1982 after completion of transfer of the supernatant liquid to Tank C-103 in 1975. Photographs of Tank C-102 now show only a dry, lumpy sludge surface.

\section{Safe Storage of TBP-NPH Solvent in Tank C-103}

Several important factors act to preclude initiation of an organic vapor fire in Tank C-103 and make it safe to continue to store, for an interim period, a separate layer of TBP-NPH solvent in Tank C-103.

- The maximum temperature in Tank C-103 was $52^{\circ} \mathrm{C}$ (Borsheim and Kirch 1991)

- The flash point of a 30 vol\% TBP-NPH solvent is $77^{\circ} \mathrm{C}$ (Borsheim and Kirch 1991)

- There are no heat sources in Tank C-103 which can raise the temperature to the flash point.

- The vapor pr sure of water is much higher than that of $\mathrm{NPH}$ at temperatures above $72{ }^{\circ} \mathrm{C}$, a temperature beiow the flash point of $30 \mathrm{vol} \%$ TBP-NPH solvent. Water vapor in the gas mixture above the liquid surface will prevent combustion (Mirabella and Willis 1977). Because of its high heat capacity, much of the heat required to burn organic vapors is expended in heating water vapor.

Concerning the $77^{\circ} \mathrm{C}$ flash point of $30 \mathrm{vol} \%$ TBP-NPH, Borsheim and Kirch (1991) point out that the flash point of a flammable liquid represents the lowest temperature at which the liquid gives off enough vapor near its surface to ignite when contacted by a spark or a flame. Below the flash point, the fuel mixture in the vapor space is too lean to burn.

Borsheim and Kirch also note that, under normal storage conditions, no spark or flame sources exist in Tank C-103 which could ignite a mixture of solvent vapor and air if such a mixture was somehow formed. But, according to Borsheim and Kirch (1991), photographic flash equipment, which is not explosion proof, if lowered into Tank C-103 could conceivably ignite a flammable fuel-air mixture if one were present. However, photographs were taken in the early 1990 s without any problems. 
Although not fully documented, results from an analysis of a sample of the organic in Tank C-103 indicated that the composition was closer to $70 \%$ TBP-NPH. These results will be validated when the results of a new analysis become available in 1993.

\section{Potential Release of Volatile Organic(s) from Tank C-103}

\section{Introduction}

Since the early 1980 s there have been sporadic indications by C-tank farm workers that one or more volatile organic compounds may be escaping into the tank farm environment from Tank C-103. In some instances, tank farm workers have required medical attention and treatment after reportedly inhaling vapors present in the atmosphere of the farm. ${ }^{\text {(a) }}$ Such medical treatment has, so far, not pinpointed an exact cause for the worker's symptoms and certainly has not singled out a particular volatile organic compound as the causative agent.

Nevertheless, cumulative evidence for release of one or more volatile organic materials from Tank C-103 continues to mount and accumulate. Faced with this situation, Westinghouse Hanford Co., the current Operating and Engineering contractor at the Hanford Site, has recently (Hanford Reach 1992) elevated the vapor issue to a top safety priority in the same category as Tank SY-101.

\section{Analysis of Tank C-103 Vapor}

In recognition of the potential health hazards presented by the release of potentially toxic gases from Tank C-103, attempts were made in 1988-1989 to sample the vapor space of Tank C-103 and to determine its composition of the vapors by gas chromatographic and mass spectroscopic analyses. Details of the cryogenic sampling equipment and procedures and of the analytical data are provided in a report (Ulbricht 1991 ) issued in 1991. Kirch (Appendix C) has recently prepared a table summarizing the analytical data obtained from analysis of the 1988-1989 gas samples. Kirch's summary table is reproduced here as Table 3.1. Kirch's letter reproduced here as Appendix $C$ of this report, provides a more detailed listing of the concentration of various individual constituents of the vapor space in Tank C-103 as determined by analysis of samples taken in 1989.

Great care and caution should be taken into consideration and evaluation of the data shown in Table 3.1 and Appendix C. Various individuals, including Kirch (1992), have recently expressed doubts that the cryogenic samples obtained in 1988 and 1989 were taken properly and, hence, they may not have been representative of the vapor space in Tank C-103. Also, in some cases, analytical methods which had not been fully developed and validated were used to analyze the gas samples. Thus, as Kirch notes, "---it is possible that several of the smaller concentration constituents may be artifacts of the detection system rather than components in the vapor space of the tank."

(a) Many C-farm workers have reported detecting the odor of ammonia, and some have reported an odor similar to "rotten tennis shoes." 
Nevertheless, the data in Table 3.1 and Appendix C. are all that are currently available (Fall 1992) concerning the composition of the vapor in Tank C-103. These data show that the major components of the vapor in 1988-1989 were, as expected, water and NPH. Also, not too surprisingly, some ammonia and nitrogen oxides were present in the vapor.

Table 3.1. Summary of Constituents in Tank C-103 $\operatorname{Vapor}^{(a)}$

Category

1. Water

2. Normal Paraffin Hydrocarbon

3. Ketones: acetone, hexanone, etc.

4. Ammonia

5. Nitrogen oxides: $\mathrm{N}_{2} \mathrm{O}, \mathrm{NO}_{x}$. etc.

6. Low molecular weight alcohols: n-butanol, alkoxyalcohols, etc.

7. Acidic gases: $\mathrm{H}_{2} \mathrm{~S}, \mathrm{HCN}, \mathrm{HF}, \mathrm{SO}_{2}, \mathrm{SO}_{3}$, etc.

8. TBP

9. Hydrogen

10. Aromatic hydrocarbons

11. Halogenated aliphatic hydrocarbuns

12. Cellosolve fragments: butyl cellosolve $\left.\mathrm{C}_{4} \mathrm{H}_{9} \mathrm{OC}_{2} \mathrm{H}_{4} \mathrm{OH}\right)$

13. Methylamine

14. Vinyl hydrocarbons

15. Acetonitrile

16. Carbon disulfide

17. Low molecular weight organic acids: acetic acid, etc.

\section{Concentration, ppm}

$<97,800$

3,500

2,300

370

250

210

85

20

15

3

1

1

$<10$

$<1$

$<1$

$<1$

$<1$

(a) Data from Kirch (Appendix C)

Again, with due consideration of their validity, the results in Table 3.1 also show that what appear to be significant concentrations of low molecular weight ketones and alcohols were present in the vapor in Tank C-103. Normal butanol is, of course, known both as an impurity in commercially-available TBP and also as a hydrolytic/radiolytic degradation product of TBP. Oxidation of $n$-butanol yields butyric 
acid, a compound well known for it distinctive rancid ("old tennis shoes") odor. The origin of the low molecular weight ketones is not immediately apparent.

\section{Current Status}

The primary recommendation from their investigation was, predictably, that more and better samples need to be taken of the vapor space in Tank C-103 before the vapor exposure problem can be solved. Obtaining an adequate number of truly representative samples is the essential first step in characterizing the source and identity of the troublesome vapors. An important corollary of this first need is that highly sensitive and capable methods and instruments be available to analyze vapor samples when they are obtained.

Because of the potentially toxic vapor problem, workers in C-farm are required to work in suppliedair protective clothing. Other measures taken to prevent inhalation of toxic vapors include increases in the staff of industrial hygienic professionals assigned to tank farms; development of an epidemiological study of tank farm vapors; and institution of a 24-h odor reporting hotline. 


\section{Remaining Scientific Issues}

As already pointed out, our current knowledge of the identity, amount, and specific chemical and physical properties of organic materials in Hanford Site SSTs is very limited. Understandably, therefore, there are a number of major unresolved scientific issues. Hill and Babad (1991) note that the overall scope of work to resolve known safety and technical issues associated with the organic tanks includes experimental work to close the scientific issues listed here.

- Issue 1. Behavior and Reactions of Organic Compounds in Existing Underground Tank Environments - The paramount scientific issue is, of course, how do the various organic compounds present in the eight organic tanks behave and what reactions do they undergo under the conditions (e.g., temperature, aqueous waste composition, radiation field, etc.) now existing in the tanks? Resolution of this complex issue not only requires that other scientific issues (Issues 2 and 3 ) be resolved, but will surely also require design and execution of experiments in which simulated tank wastes containing both representative inorganic and organic components are maintained for varying periods of time under conditions which approximate, as closely as convenient, those now prevailing in the organic tanks.

- Issue 2. Types and Amounts of Organic Compounds - An important scientific issue is to obtain by analysis of representative samples, quantitative information concerning the types and quantities of the various organic compounds in the eight organic tanks. Such knowledge is essential to proper and efficient further actions---interim storage, mitigation, remediation---of the contents of the organic tanks. Such analyses may also show that certain tanks currently listed on the organic tank watch, e.g., S-102, TX-118, U-106, do not contain sufficient organic material to warrant their inclusion on the watch tank list.

- Issue 3. Knowledge of Selected Physical and Chemical Properties of Organic Compounds - Detailed knowledge of selected and relevant physical and chemical properties of organic compounds known to be present in the organic tanks will provide an invaluable scientific basis and tool for classifying and ranking the potential hazards and safety-related concerns for individual organic compounds and selected mixtures thereof. Examples of physical and chemical properties of interest include boiling points, melting points, flash points, vapor pressures, enthalpies of combustion, solubility in aqueous solutions, and reaction (oxidation) with mixtures of $\mathrm{NaNO}_{3}$ and $\mathrm{NaNO}_{2}$. Table 4.1, taken from Hill and Babad (1991) lists additional properties to be determined by thorough characterization of wastes in the organic tanks.

- Standard literature sources, e.g., handbooks, will likely provide much of the data needed to complete a tabulation of selected physical and chemical properties of candidate organic compounds. In some cases, e.g., reaction with solid $\mathrm{NaNO}_{3}$ and/or $\mathrm{NaNO}_{2}$, desired data will likely need to be obtained by appropriately designed and executed bench-scale experiments.

- A suitably comprehensive physicochemical property data base for organic compounds present in the organic tanks may enable development of an appropriate computer program to 
Table 4.1. Organic Tank Waste Characterization Needs ${ }^{(a)}$

- Chemical analysis to determine concentrations of:

- organic constituents

- oxidizing salts

- diluents

- potential catalysts

- reaction Initiators

- Determination of the spatial distribution in the tanks of the organic waste constituents and other constituents that may interact with them.

- Determination of physical and chemical parameters:

- reaction initiation temperatures

- reaction enthalpies

- reaction propagation rates.

- Estimates of sensitivities to reaction triggering phenomena:

electrostatic discharges

- physical shock waves (impacts)

- friction

- radiation, nuclear and electromagnetic

- crystal energy relaxations

- effect of temperature on triggering mechanisms.

(a) Reproduced from Hill and Babad (1991)

model and predict the temperature-long time behavior of mixtures of inorganic and organic constituents in the organic tanks. Alternatively, one of several already-existing computer codes for modeling the progress and extent of reactions taking place in complex chemical systems may be able to utilize as input the physical and chemical properties of the organic compounds in the organic tanks.

-Issue 4. Source, Composition, Quantity, and Properties of Volatile Organic Compounds - Appropriate field and laboratory data need to be collected to establish the source and amount of the presently-unidentified volatile organic compound(s) apparently evolving from Tank C-103. Circumstantial evidence continues to mount that some unidentified organic material(s), which adversely affects the health of tank farm workers, is evolving from Tank C-103. The surrent data base is inadequate to establish unequivocally whether or not organic materials are being released from Tank C-103. Much more knowledge of the inventory of organic chemicals in Tank C-103 and their properties is needed to determine exactly what health hazards are presented by possible emanations from this tank and how to mitigate and remediate them. 


\section{References}

Allen, G. K. 1976. Estimated Inventory of Chemicals Added to Underground Waste Tanks, 1944 through 1975. ARH-CD-6108, Atlantic Richfield Hanford Co., Richland, Washington.

Beitel, G. A. 1976a. Chemical Stability of Salt Cake in the Presence of Organic Materials. ARH-LD119, Atlantic Richfield Hanford Co., Richland, Washington.

Beitel, G. A. 1976b. Sodium Nitrate Combustion Limit Tests. ARH-LD-123, Atlantic Richfield Hanford Co., Richland, Washington.

Beitel, G. A. 1976c. Final Report on Investigations of Stability of Organic Materials in Salt Cake. ARH-LD-126, Atlantic Richfield Hanford Co., Richland, Washington.

Beitel, G. A. 1977. Exothermic Potential of Sodium Nitrate Salt Cake. ARH-LD-163, Atlantic Richfield Hanford Co., Richland, Washington.

Borshiem, G. L., and N. W. Kirch. 1991. Summary of Single-Shell Tank Siability. WHC-EP-0347, Westinghouse Hanford Company, Richland, Washington.

Burger, L. L., and R. D. Scneele. 1988. Interim Report on Cyanide Safety Studies. PNL-7175, Pacific Northwest Laboratory, Richland, Washington.

Burger, L. L., D. A. Reynolds, W. W. Schulz, and D. M. Strachan. 1991. A Summary of Available Information on Ferrocyanide Tank Wastes. PNL-7822, Pacific Northwest Laboratory, Richland, Washington.

Fisher, F. D. 1990. The Kyshtym Explosion and Explosion Hazards with Nitrate-Nitrite Bearing Wastes with Acetates and Other Organic Salts. WHC-SD-LB-033, Westinghouse Hanford Co., Richland, Washington.

Hainer, R. M. 1955. Application of Kinetics to the Hazardous Behavior of Ammonium Nitrate. 5th International Symposium on Combustion, Pittsburgh, 30 Aug 1954, Reinhold Pub. Co., New York.

Hall, J. C. 1972. ARHCO-2424. Engineering Study-Liquid Organic Waste Collection And Disposal. Atlantic Richfield Hanford Co., Richland, Washington.

Hanford Reach. 1992. "More Sampling Needed to Solve Vapor Mystery," June 15, 1992 edition, p.8, Westinghouse Hanford Company, Richland, Washington.

Hanlon, B. M. 1989. Tank Temperature Data Review. Report WHC-CM-5-7, Westinghouse Hanford Co., Richland, Washington. 
Hill, R.C.P., and H. Babad. 1991. High Organic-Containing Tanks: Assessing the Hazard Potential, WHC-SA-1218, Westinghouse Hanford Company, Richland, Washington.

Jungfleisch, F. M. 1984. Preliminary Estimates of the Waste in Hanford Tanks Through 1980. SD-WMTI-057, Rockwell Hanford Co., Richland, Washington.

Kirch, N. W. 1982. HEPA Filter Plugging in 241-A-702 Vessel Ventilation System. SD-WM-TI-029, Rockwell Hanford Operations, Richland, Washington.

Kirch, N. W. 1983. The Effects of Ammonia Containing Wastes on Future Waste Management Systems. SD-WM-TI-056, Rockwell Hanford Operations, Richland, Washington.

Klem, M. J. 1990. Inventory of Chemicals Used at Hanford Site Production Plants and Support Operations (1944-1980). WHC-EP-0172, Westinghouse Hanford Co., Richland, Washington.

Medvedev, Z. A. 1977. "Facts Behind the Soviet Nuclear Disaster," New Scientist 74 (1058), 761-764.

Mirabella, J. E., and N. P. Willis. 1977. ARHCO-CD-719. Operational Safety Analysis Double-Shell Waste Storage Tanks. Atlantic Richfield Hanford Co., Richland, Washington.

Nikipelov, B. U. et al. 1989. Accident in the Southern Urals on 29 September 1957. Report distributed by the International Atomic Energy Agency, Vienna, Austria.

Parker, F. L. 1978. Analysis of the Medvedev Report of a Soviet Radioactive Waste Incident. Vanderbilt University, Nashville, Tennessee.

Putnam, R. C. 1977. Explosion Hazard Potential of Simulated Salt Cakes. HRC-3808-1, Hazards Research Corp. Denville, New Jersey.

Reynolds, D. A., D. D. Siemens, D. M. Strachan, and R. W. Wallace. 1991. A Survey of Available Information on Gas Generation in Tank 241-SY-101. PNL-7530, Pacific Northwest Laboratory, Richland, Washington.

Schulz, W. W. 1980. Removal of Radionuclides from Hanford Defense Waste Solutions. RHO-SA-51, Rockwell Hanford Operations, Richland, Washington.

Shoun, R. R., and M. C. Thompson. 1984. "Chemical Properties and Reactions," In Science and Technology of Tributyl Phosphate, W. W. Schulz and J. D. Navertil, eds., CRC Press, Inc., Buca Raton, Florida.

Soran, D. M., and D. B. Stillman. 1982. An Analysis of the Alleged Kyshtym Disaster. LA-9217-MS, Los Alamos National Laboratory, Los Alamos, New Mexico. 
TASS. 1989. June 6 Edition. TASS News Science, USSR.

Ulbricht, W. H., Jr. 1991. Report on 241-C Tank Farm Air Sampling Results of 1989. WHC-SD-WMRPT-019, Westinghouse Hanford Co., Richland, Washington. 


\section{Appendix A}

\section{Historical Perspectives of Wastes in Tank 241-C-103}

Copy of Internal, Memo, F. M. Jungfleisch to K. G. Carothers,

Westinghouse Hanford Co.,

November 6, 1987 
Environmental Management and Technology Unit 3-1026 2750E/D274/200E

October 2, 1987

Fistorical Perspectives of Wastes in Tank 216-C-103

Letter Number

\section{R.G. Carothers 2750E/A216/200E}

\section{Overvien}

In early September 1987, exposure to vapors from tank 216-C-103 caused three workers to suffer health effects that resulted in time-loss injuries. The exposure occurred when the workers were attempting to photograph the interior of the tank. At that time, the void space in the tank was obscured by a "millky" mixture of saturated air and some condensed phase or condensed phases. I have been requested to report the types of wastes that have been stored in C-103 and to identify alternative tanks that have had similar histories.

Tank C-103 has received waste directly, as the second tank in a twotank cascade, and as the third tank in a three-tank cascade. Over time it has received about 30 unique types of waste. These wastes have been generated by four primary recovery processes, two secondary recovery processes, evaporators, in-tank solidification, semi-works operations, decontamination operations, $\mathrm{N}$ reactor, Battelle Northwest Laboratory, and both in-process and in-tank waste scavenging. Tank C103 has received wastes from primary and secondary recovery processes, from other tanks in the 216-C tank farm, directly from tanks in tank farms 216-A and 216-C, and indirectly from tanks in tank farms 216-A, 216-AX, 216-B, 216-BX, 216-BY, 216-S, 216-SX, 216-T, 216-TX, 216-TY, and 216-U. Tank $\mathrm{C}-103$ has been an accumulator tank for metal waste from other tanks before processing for uranium recovery and for supernatants from other tanks before processing for cesium recovery.

In my judgement, no Hanford underground storage tank bears the same unique waste signature of tank $\mathrm{C}-103$. Indeed, the tank is an arterial on the Hanford road map; it doesn't seem to be a place as much as a path over which nearly every type of Hanford, high-activity has passed. However, the tanks that have provided waste to tank C-103 are good candidates for resolving this problem. The wastes were generated by process activities and non-routine ativities. A very small number of tanks were the primary receivers for the non-routine wastes. One form of semiworks waste was discharged to tanks 216-C-107, 216-C-111 and 216-C-112. The other form of this was was discharged to a two tank cascade that consisted of $216-\mathrm{C}-203$ and 216-C-204. Tank 216-T112 has received a large amount of decontamination waste. Likewise, all of the $\mathrm{N}$ Reactor waste and the Battelle Northwest waste that has been received by tank C-103 has originated at tank 216-U-107.

\section{History}

The data sources that have been used in this study suffer from missing and conflicting information, from partial development, and from the fact that they have not been developed for this type of application. 
This study is, necessarily, only qualitative. It does not postulate composition information. It does not provide estimates of the relative importance of various waste sources on the current inventory of tank C-103. It may include as waste sources, waste types that have been totally removed from a source tank prior to transfer of waste to tank C-103; that is, this study may overestimate the importance of some waste types in the current tank $\mathrm{C}-103$ inventory. In the subsequent discussion the "216-" portion of designations will be assumed for all tanks.

The waste management transactions that have been evaluated for tank C103 in this study span the period from March 1946 through December 1975.

The first phase of tank C-103 operations deals with the addition of Metal Waste (MW) from the Bismuth Phosphate primary recovery process, sluicing of the $\mathrm{WW}$ to provide feed to the Uranium Recovery secondary recovery process, and receipt of Tributyl Phosphate (TBP) waste from Uranium Recovery. From March 1946 through October 1946 the C-101/C102/C-103 cascade was filled by cascading MW into C-101 and then into $\mathrm{C}-102$ and then into $\mathrm{C}-103$. At no subsequent time did waste enter C103 from a cascade that originated with C-101. Tank C-103 began to provide feed to the Uranium Recovery secondary recovery process in December 1952. It accumulated MW from BY-103, C-101 and C-102 and provided that waste to Uranium Recovery until May 1953. At that time, tank C-102 was empty and the residual heel in tank C-103 was about 10,000 gallons. TBP received in this cascade from May 1953 through January 1954. The neutralized TBP from the process was added to C-101 and later to C-102. TBP supernatant was transferred from C-101 to C103 and TBP waste was cascaded into C-103 from C-102.

The second phase of tank C-103 operations is associated with in-tank and in-process scavenging activities. These activities attemnted to reduce solution concentrations of cesium and strontium in TBI and the First Cycle Decontamination (1C) waste from the Bismuth Phosphate process. During April and May or 1957, the TBP supermatant from C-103 was scavenged and solids were permitted to settle in tanks C-111 and $\mathrm{C}-112$. The residual heel in tank $\mathrm{C}-103$ was about 25,000 gallons.

In the third phase of tank C-103 operations, Coating Waste (CWP) from the PUREX primary recovery process and other PUREX wastes were discharged directly into tank C-103 or cascaded into C-103 from their primary receiver, tank C-102. This period extends from April 1960 through the last calendar quarter of 1969. Very substantial amounts, about 13,000,000 gallons, of CWP were received directly and by cascading at C-103. Tank C-102 was the primary receiver for the other PUREX wastes which cascaded to $\mathrm{C}-103$. They include 430,000 gallons of Thoria (TH) waste and 1,833,000 gallons of Organic Wash (OWW) waste. These large quantities could be accommodated in the two tank cascade with a total nominal volume of $1,060,000$ gallons because tank C-103 was also functioning as a supernatant feed tank to the Cesium Recovery secondary recovery process.

The fourth phase of tank C-103 operations overlaps the third phase. 
It is associated with waste transfers to $\mathrm{C}-103$ or cascades to C-103 that resulted from waste transfers to $\mathrm{C}-102$. The period extends from June 1957 through July 1970. The transferred wastes were supernatants from tanks in the 200 East Area that were either primary receivers or secondary receivers of waste from other tanks in the 200 East Area.

Many primary waste sources are represented in the supernatants in phase four. Bismuth Phosphate process wastes include 1C, a First Cycle Decontamination System Flush (1CF) and the Second Cycle Decontamination (2C) waste. PUREX wastes include CWP, OWW, PUREX High-level (P) waste, PUREX Low-level (PL) waste, Carbonate Wash (CARB) waste and Inorganic Wash (IWW) waste. The secondary recovery process wastes include TBP from Uranium Recovery and B Plant Highlevel (B), B Plant Low-level (BL) waste, Cesium Recovery (CSR) and Strontium Recovery (SRR) waste from Fission Product Recovery. Hot Semiworks (HS) waste was generated during the development of the Fission Product Recovery process. Supernatants from Evaporator Bottoms (EB) were received at $\mathrm{C}-103$ from concentrating $1 \mathrm{C}, 2 \mathrm{C}$ and TBP supernatants. Supernatants were also received at C-103 from In-tank solidification (ITS) product. Finally, supernatants were received from the heels of 13 in-tank scavenge campaigns and 11 in-process scavenge campaigns after the solids precipitated and settled and after the low-activity supernatant was removed for soil column disposal.

The fifth phase of tank $\mathrm{C}-103$ operations is analogous to phase four except supernatants were received from primary and secondary source tanks in the 200 East Area and the 200 West Area and the supernatants include several, low-volume, "customer wastes". The period of this phase extends from the third calendar quarter of 1972 through the fourth calendar quarter of 1975. Neither C-102 nor C-103 functioned as a primary waste receiver during this interval.

The primary waste sources that are represented by the primary and secondary waste sources for the phase five transfers include many of those that appeared in phase four. These redundant sources are 1C, $P$, PL, CWP, OWW, CARB, IWW, TBP, B, BL, CSR, SRR, HS, and all the in-tank and in-process scavenge campaigns listed in phase four. Ancillary sources include First Cycle Supernatant (1CS) from the Bismuth Phosphate process, Redox High-level (R) waste Redox High-level Supermatant (RSN) and Redox Coating Removal (CRW) waste from the Redox primary recovery process, PUREX Sludge Supernatant (PSS) from the PUREX process, Strontium Semiworks (SSW) waste, N Reactor (N) waste, Battelle Northwest (BNW) waste, Decontamination (DW) waste, and supernatants from the heels of 16 additional in-tank and 39 in-process scavenge campaigns after the low-activity supernatants are removed for soil column disposal.

The HS, SSW, DW, N, and BNW supernatants that were received by C-103 were transferred from C-104. The transferred supernatants were received by C-104 from other, primary receiver tanks. Tank C-107 received HS from the fourth calendar quarter of 1964 through the fourth quarter of 1967 . Tank C-111 received HS from the forth quarter of 1962 through the second quarter of 1964. Tank C-112 received HS from the fourth quarter of 1961 through the second quarter of 1962. 
The cascade C-203/C-204 received SSW during the first and second quarters of 1970. Tank T-112 began receiving DW in the fourth quarter of 1967. Supernatant containing DW was transferred from T-112 to U1107 in the second quarter of 1973. Additionally U-107 received $\mathrm{N}$ and $\mathrm{BNW}$ from the third quarter of 1972 through the fourth quarter of 1973. Transfers from the $\mathrm{C}$ farm tanks to $\mathrm{C}-1014$ occurred prior to the supermatant transfer to $\mathrm{C}-103$ from $\mathrm{C}-1014$ in the second quarter of 1973. Six supernatant transfers were made from C-104 to C-103 after the transfers fram $\mathrm{U}-107$ to $\mathrm{C}-1014$ in the second fourth quarters of 1973.

\section{Evaluation}

Without detailed composition data on the waste sources that were introduced into tank $\mathrm{C}-103$, it is not possible to specify all of the hazardous chemical or radiochemical substances that can cccupy the void space of the tank. However, several generalities seem reasonable and pertinent.

The toxic species that caused the incident could be volatile or nonvolatile. The "milky" mist in the tank void space could have been swept into the atmosphere of the work area by several plausible mechanisms; personnel insult by substances in condensed phases cannot be excluded without consideration. However, the toxic, volatile species are the principal concern.

The preponderant source of waste in underground storage originated from primary and secondary recovery processing. Ammonium fron CWP and degradation products of tributyl phosphate from TBP are the most obvious sources of toxic, volatile species.

Toxic substances in the supernatants could have been received at $\mathrm{C}-103$ in wastes from processing activities or in wastes from non routine sources. The distinction between these waste sources is important; almost all of the underground tanks have received only process-related waste and only a few have received the non routine wastes. If the problem results from contaminants in wastes from processes, it will require a redefinition of all Hanford waste management priorities. If the contaminants are components of non routine wastes, they can be identified by sampling the void spaces of the primary receivers and remediation can be performed on a limited scale.

A cursory review of the process-related supernatants does not reveal a candidate compound. The heels from the scavenge campaigns should contain substantial amounts of hexacyanoferrate (II) ion which Battelle Northwest. Laboratory continues to consider as a cyanide source. Organic compounds in other process wastes are not significant. Since hexanone is slightly soluble in water, the small amount of hexanone that entered $\mathrm{C}-103$ with the small amount of Redox supernatants would have been almost entirely removed with succeeding transfers from the tank. The same is true for the PUREX diluent, a mixture of normal paraffin hydrocarbons.

The chemical content of HS, SSW, HS, DW, BNW and N wastes could 
contain volatile species and could degrade to generate volatile species. The chemical content of the DW is particularly difficult to postulate because of the proprietary products that are frequently used for decontamination. The HS and SSW wastes were discharged from the semiworks at different times. It is not clear SSW is a final load out from the same development work that generated HS. They could have been generated by different development activities. The content and uniformity of the BNW waste over time is unknown.

F.M. Jungfleisch, Scientist

Environmental Management and Technology Unit 


\section{Appendix B}

\section{Tank C-103 Transaction History-Post 1976}

Copy of Internal Memo, K. G. Carothers to Distribution,

Westinghouse Hanford Co.,

September 22, 1988 


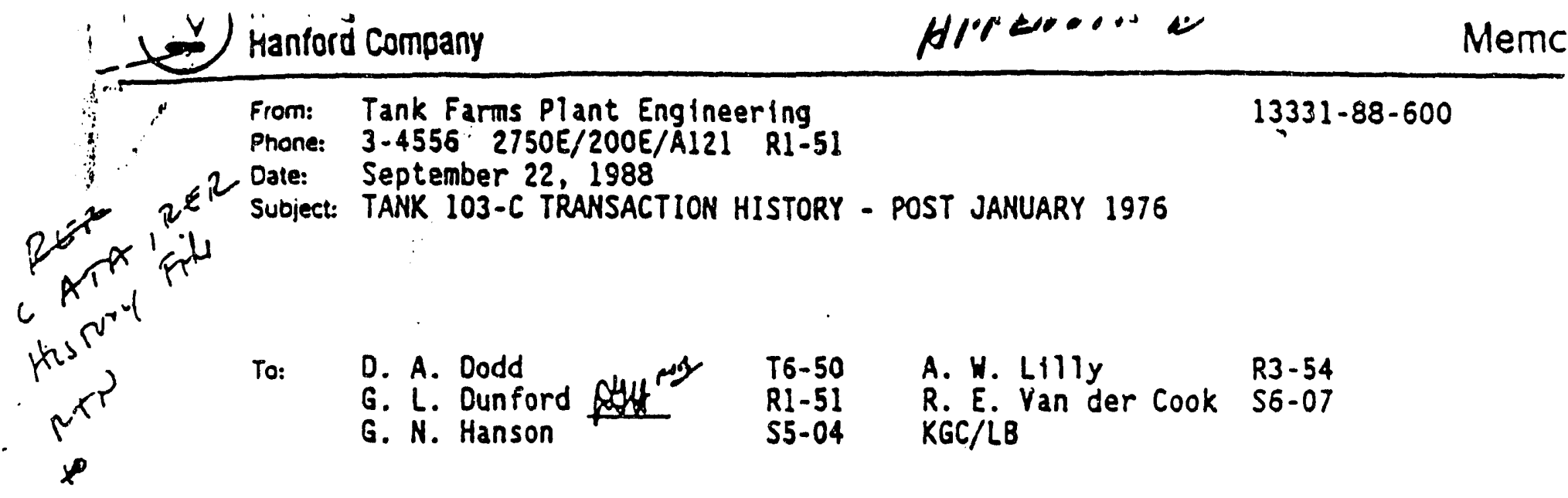

References: (1) Internal Memo, D. A. Dodd to K. G. Carothers,
"Final Report of Tank Vapor Space Sampling of
$241-C-101,-102$, and $-103, "$ May 4, 1988.

(2) Internal Memo, F. M. Jungfleisch to K. G.

Carothers, "Historical Perspectives of Wastes in Tank 241-C-103," November 6, 1987.

(3) RHO-CO-213, Vol. II, Waste Storage Tank Status and Leak Detection Criteria, Revised February 11, 1984.

(4) Internal Letter, J. C. Hall to R. C. Roal, "Safety Analysis - Storage of Organic Waste in Underground Tanks," June 27, 1972.

(5) Internal Letter, T. D. Anderson to W. L. Godfrey, "Organics in 102-C Tank," October" 2, 1969.

The Reference (2) memo summarizes an evaluation of waste management transactions for tank 103-C spanning the period from March 1946 through December 1975. The objective of this evaluation was to determine the types of wastes that were sent to the tank and to identify tanks with similar histories. A review of tank farm surveillance records for tank 103-C shows that waste transactions actually occurred through July 1979. Thus, this memo extends the transaction history from the December 1975 date to the present time.

Tank 103-C remained active until July 1979, after which no wastes were transferred into or out of the tank. During the period in question, the tank served as a primary receiver for insoluble strontium-leached solids from both $B$ PIant and AR Vault during the PUREX Acidified Sludge (PAS) secondary recovery operations. Other wastes transferred into tank $103-C$ originated from supernatant pumping tanks in the 200 East Area that were historically either primary receivers of waste or secondary receivers of waste from other tanks. Tanks involved in these transiers included tanks $107-C, 108-C, 109-C, 110-C, 111-C$, and 112-C. Besides the PAS strontiumleached solids, other waste types contributing to the tank transactians include Hot Semiworks Waste (HS), Cesium Recovery Waste (CSR) and

B.1

RIECEIVED SEP 281988 
Strontium Recovery Haste (SRR) from Fission Product Recovery, B Plant High-Level Waste (B), B Plant Low-Leyel Waste (BL), PUREX Coating Waste (CWP), PUREX Organic Wash Waste (OWX), PUREX Low-Level Waste (PL), PUREX High-Level Haste (P). Thoria Haste (TH), Strontium Semiworks Haste (SSW), $N$ Reactor Haste (N), Battelle Northwest Haste (BNM), and Decontanination Waste (OH).

Most of the supernate that remained in tank 103-6 after removing it from service in July 1979 probably originated from wastes added subsequent to May 12, 1977. At that time, the tank was pumped down to a minimum liquid level of 31.4 inches. The sludge levels reported for the first quarter 1977 and third quarter 1977 were 20 inches and 50 inches respectively. At most, about II inches of supernate remained after pumping to the above minimum level. Much of this heel (if aqueous) could have been removed during the subsequent nine fill/decant cycles that occurred prior to deactivating the tank.

The major source of waste received in tank 103-C during the last two fill/decant cycles originated from tank $107-C$. A best estimate of waste types in tank 107-C at the time shows $N, B N H$, and DN received from tank 104-C via tank 107-U. The records al so show minor quantities of waste originating from tank A-101 (SRR and PL waste) and PUREX High-Level Waste (P) being received in tank 104-C prior to making the final waste transfer into tank 107-C. Secondary sources of waste over this period includes about 0.2 inch from tank $109-C, 2.6$ inches from tank $110-C$, and 1.2 inches from tank 112-C. The most likely origin of waste in these tanks is tank 110-C, tank 103-BX, and tank 110-C, respectively. Haste types from these secondary sources include $B, B L, C S R$, CWP, and OWW.

One final possibility to consider is the presence of a separable organic phase in tank 103-C resulting from transfer of waste from tank $102-C$. Such a layer is suspected due to a total organic carbon (TOC) concentration of $7400 \mathrm{ppm}$ (parts per million) measured on a surface sample taken from the tank in September 1987 (Reference [1]). The last transfer from tank 102-C occurred on November 14, 1975, during $P-10$ pumping stabilization efforts, with the waste routed to tank 103-C. Subsequent tank 102-C photographs taken on May 18, 1976, "revealed a dry, lumpy surface of sludge with very shallow puddles of liquid visible." (Reference [3]) Prior to the November 1975 P-10 pumping, tank $102-C$ had stood inactive since the fourth quarter of calender year 1969. During this same quarter, a 10 to 13 inch deep top layer of organic was found in the tank (Reference [5]). Because tank 102-C had been a receiver for PUREX OWW, the 36,000 galion organic waste inventory was taken to be a mixture of tributy)-phosphate and normal paraffin hydrocarbons (TBP-NPH) (Reference [4]): Given the success in pumping tank 102-C down below the sludge level, it is likely that a portion of the organic layer was transferrad :0 tank 103-C. Also, because of its lower specific gravity, the organic would nust likely remain in tank $103-C$ during subsequent iill/decant cycles. 
Given the tank 103-C transactions occurring between December 1975 and July 1979, other candidate tanks for containing waste similar to that stored in tank 103-C include tank $104-C$ and tank $107-C$. As discussed above, the majority of the liquid waste presently stored in tank 103-6 (excluding any floating organic layer originating from the earlier tank 102-C transfer) was received from tank 107-C. Tank $107-6$ has stood inactive since completing the tank 103-6 transfers. Similarly, the last transfer made from tank $103-C$ was routed to tank $104-6$ and represents the last receipt of waste by tank 104-C.

In conclusion, the tank 103.C transaction history for the period December 1975 until the present time basically substantiates the findings of the Reference (2) study with only one exception. The important findings are summarized below along with the single exception.

- Detailed composition data on the waste sources contributing to the tank inventory are required in order to assess the hazardous chemicals that could occupy the tank vapor space.

- A mixture of TBP-NPH organic and associated degradation products from PUREX Plant processing activities is probably present in the tank. This represents an exception to the earlier study findings.

- OW, BNW, and $N$ wastes may contain chemicals or degradation products of chemicals that could exhibit volatility. Because many of the products used in decontamination operations are proprietary, knowledge of the chemical make up of these products are unknown.

- Tank 104-C and tank 107-C represent high potential candidate tanks to investigate for problems similar to those experienced in tank 103-C.

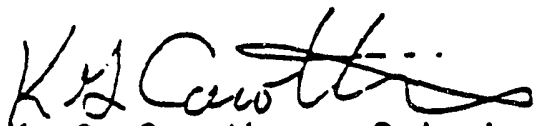

K. G. Carothers, Principal Engineer

Tank Farms Plant Engineering 
Appendix C

Tank 241-C-103 Vapor Constituents, Copy of Internal Memo, N.W. Kirch, to C.W. Dunbar, Westinghouse Hanford Co., March 5, 1992 
From: Tank Waste Technology Applications

Phone: $\quad 3-2380$ R2-11

72100-92-033

Date: $\quad$ March 5, 1992

Subject: TANK 241-C-103 VAPOR CONSTITUENTS

To:

C. W. Dunbar R1-30

\begin{tabular}{|c|}
\hline $\begin{array}{l}\text { H. Babad } \\
\text { K. G. Carothers } \\
\text { R. B. Conrad } \\
\text { J. L. Deichman } \\
\text { J. D. Hopkins } \\
\text { M. J. Klem } \\
\text { J. M. Miller } \\
\text { J. G. Propson }\end{array}$ \\
\hline
\end{tabular}

D. A. Reynolds

M. A. Payne

A. W. Lilly

R. B. Lucke

J. W. McMuellen

J. D. Thomson

W. H. Ulbricht

NWK File/LB
R2-11
$R 2-50$
$\mathrm{T} 1-05$
P8-08
$\$ 5-14$
Ri -30
G6 -50

Reference: 1) Letter, N. W. Kirch to C. W. Dunbar, same subject, 72100-92 -025, February 19, 1992.

2) Document, WHC-EP-0424, "Vapor Space Sampling Criteria for Single-Shell Tanks Containing Ferrocyanide Waste", dated July
1991.

3) Document, WHC-SD-WM-RPT-019, "Report on 241-C-Tank Farm Air Sampling Results of 1989", dated June 1991.

4) Letter, K. G. Carothers to D. J. Washenfelder, "Tank 103-C Characterization Fiscal Year 1989 Work Scope", 13331-89-020,
January 18, 1989.

This letter updates the information of Reference 1 as the design basis for a new ventilation system to remove toxic chemical vapors from the single-shell tanks and improve protection of personnel. The initial information was expanded to include additional constituents and the maximum concentration observed in the vapor space of tanks $241-C-101,241-C-102$, and 241-C-103. We understand this three tank cascade will be connected to a single forced air ventilation system.

This letter uses a combination of limited analytical chemistry results and best engineering judgement to identify, categorize, and quantify the volatile constituents. Most of the single-shell tanks are passive vent $i l$ ated and have a seasonal average void volume air exchange rate of about $0.6 \%$ based on average daily barometric pressure changes (Reference 2). Tanks $241-C-101$ and $241-C-102$ are vented through tank $241-C-103$ to the atmosphere. Tank 241-C-103 has a treatment system for removal of organic and ammonia vapors.

The design basis for the vapor space constituents is summarized in Table 1. The information is based on cryogenic sample results, inorganic gas assay Energy

Hanford Operations and Engineering Contractor for the US Department of 
Page 2

March 5, 1992

results, and consensus of Hanford Site experts. The vapor concentrations were primarily obtained from 1988 and 1989 sample results (References 3 and 4). The maximum observed vapor concentrations were used for conservatism. Changes to the tables are in "Bold" type. State of the art absorption equipment such as Tenex columns [referred to as volatile organic analysis (VOA) tubes] have proved inadequate to reliably capture, identify, and quantify volatile organic compounds under many sampling conditions at the Hanford Site.

Concentrations shown are for time $=0$, before the exhaust system begins operation. The vapor concentrations will be reduced to much lower values after start up of the ventilation system and the tank comes to a steady state condition. Based on past experience, it is estimated that at least 3 months time would be required for vapors in the tank to become saturated if the forced air ventilation was stopped.

The cryogenic sample results shown in Table 2 and Attachments were collected using an unvalidated prototype sampler and analyzed by developmental type laboratory methods. The cryogenic sampler is undergoing validation tests for 1-butanol, methylene chloride, acetone, carbon disulfide, and benzene. These tests and laboratory methods are scheduled to be completed by May 1, 1992. The 1989 analytical laboratory results for the 38 constituents and ammonia (Attachment I) were confirmed by mass spectrograph and gas chromatograph methods. Information on the detection limits of the analytical methods are not currently available, therefore, it is possible that several of the smaller concentration constituents may be artifacts of the detection system rather than components in the vapor space of the tank.

Please call Mike Klem on 3-1097 or me if you have questions.

N. W. Kirch, Manager

$\mathrm{mjg}$

Attachment 
Table 1

Summary of Vapor Space Constituents

Category

Initial Concentration, $\mathrm{ppm}^{1}$

1. Normal Faraffin Hydrocarbon (NPH), $\mathrm{C}_{10}-\mathrm{C}_{14}$, possibly containing trace aromatics; and 14

3,500

saturated and unsaturated alkaline fragments

2. Ammonia

3. Nitrogen oxides, $\mathrm{N}_{2} \mathrm{O}, \mathrm{NO}_{\mathrm{X}}$

4. Low molecular wt alcohols, 1-butanol; and alkoxyalcohols

5. Halogenated aliphatic hydrocarbons

6. Tributyl phosphate (TBP)

7. Ketones, acetone, hexanone, etc

8. Vinyl hydrocarbons

9. Aromatic hydrocarbons

10. Carbon Disuifide $<1$

11. Cellosolve fragments (such

butyl cellosolve $\mathrm{C}_{4} \mathrm{H}_{9} \mathrm{OC}_{2} \mathrm{H}_{4} \mathrm{OH}$ )

12. Hydrogan suifide $\left(\mathrm{H}_{2} \mathrm{~S}\right)$, hydrogen cyanide(HCN), sulfur dioxide $\left(\mathrm{SO}_{2}\right)$, sulfur trioxide $\left(\mathrm{SO}_{3}\right)$, and other acidic gases.

13. Methylamine $\left(\mathrm{CH}_{3} \mathrm{NH}_{2}\right)$

14. Acetronile $\left(\mathrm{CH}_{3} \mathrm{CN}\right)$

15. Hydrogen

16. Water

17. Various low-inolecular wt $<1$ organic acids such as acetic acid $\left(\mathrm{CH}_{3} \mathrm{CO}_{2} \mathrm{H}\right)$.

1) ppm is part per million based on volume. See Table 2 for details of constituents. 
Table 2

Details of Vapor Constituent Concentrations

Category

1. $\mathrm{NPH}\left(\mathrm{C}_{12} \mathrm{H}_{26}\right)$

2. Ammonia

3. Nitragen oxides

$\mathrm{N}_{2} \mathrm{O}$

$\mathrm{NO}_{2}$

NO

4. Low molecular weight alcohols

1-butanol

Molecular wt,

$\mathrm{g} / \mathrm{g} \mathrm{mol}$

j. Halogenated aliphatic hydrocarbons

chloroethane

methylene chloride

chloroform

chiloromethane

dishloroethylene

dichloroethane

trich icrofluoromethane

bromoethane

carbon tetrachloride

bromodichloromethane

dichloropropane

dichloropropene

dibromochloromethane

trichloroethane

tetrachloroethylene

tetrachloroethane

trichloroethylene

Total
170

17

44

46

30

74

64.5

84.9

119.4

50.5

96.9

99

Initial Concentration $\mathrm{ng} / \mathrm{m}^{\mathrm{m}}$

PPM

$24,000 E+06 \quad 3,500$

260E+06

370

$<4.4 E+06$ (est) 2

$<4.4 E+06$ (est) 2

$<4.4 E+06$ (est) 3

627E+06

207

156.3

109

153.8

163.9

113

111

208.3

133.4

165.8

167.9

131.4

2,800

0.001

2.0E+06

0.57

41,000

0.008

$603,000^{1}$

0.29

800

0.0002

24,800

0.006

575,000

0.090

1,200

0.0003

9,300

0.001

5,600

0.0008

46,000

0.01

1,200

0.0003

400

0.0000

41,400

0.007

96,000

0.0006

58,000

0.014

4,000

0.0007

1.0 
Table 2 (continued)

Details of Vapor Constituent Concentrations

Category

6. Tributyl phosphate (TBP)

7. Ketones

acetone

2-butanone

2-hexanone

4-methyl 2-pentanone

Total

8. Vinyl hydrocarbons

vinyl chloride

vinyl acetate

Total

9. Aromatic hydrocarbons

benzene

toluene

chlorobenzene

styrene

ethylbenzene

o-xylene

Total

10. Carbon disulfide

11. Cellosolve fragments

12. Acidic gases

Hydrogen sulfide

Hydrogen cyanide

Sulfur dioxide

Sulfur trioxide

Total

13. Methylamine
Molecular wt, $\mathrm{g} / \mathrm{g} \mathrm{mol}$

266

58.1

72.1

100.1

100.2

62.5

89.1

78.1

92

112.5

104.1

106.2

106

76

90

34.1

27.1

64

80

31.1
Initial Concentration $\mathrm{ng} / \mathrm{m}^{3}$

PPM

$221 E+06$

20

$5,440 E+06 \quad 2290$

$39 E+06$

13.2

6.3E+06

1.5

2.2E+06

0.5

2315

$$
7,900^{1}
$$

0.003

$1.9 E+06$

0.54

0.54

650,000

0.20

474,000

0.13

21,000

0.004

48,000

0.011

10,400

0.002

9. $3 E+06$

2.14

2.5

118,000

0.038

NA

(est) 1

$<140,000$

(est) 0.1

$<140,000$

(est) 0.13

$<140,000$

(est) 0.05

$<140,000$

(est) 0.04

(est) 0.23

NA

(est) $5-10$ 
Table 2 (continued)

Details of Vapor Constituent Concentrations

Category

14. Acetronile

15. Hydrogen

16. Water (based on $130^{\circ} \mathrm{F}$ )

17. Low-molecular wt

organic acids

acetic acid
Molecular wt,

$\mathrm{g} / \mathrm{g}^{\circ} \mathrm{mol}$

41

2

18

60
Initial Concentration

\begin{tabular}{|c|c|}
\hline $200,000^{2}$ & 0.12 \\
\hline $1.2 E+06$ & 14.7 \\
\hline$<72,000 E+06$ & (est) $<97,800$ \\
\hline
\end{tabular}

1) Concentration of this constituent is from headspace of tank 241-C-102.

2) Based on 1991 cryogenic sample results.

3) Based on decomposition of vinyl acetate.

NA - not available

est - estimated value

ng - nanogram

ppm $\left(25^{\circ} \mathrm{C}\right)=\mathrm{ng} / \mathrm{m}^{3}(24.45 / \mathrm{g}$ molecuiar wt of substance $) \times 10 \mathrm{E}-06$ 


\section{Distribution}

No. of

Copies

\section{OFFSITE}

12 DOE/Office of Scientific and Technical Information

J. Tseng

U.S. Department of Energy

EM-35

Trevion II

Washington, DC 20585-0002

C. S. Abrams

1987 Virginia

Idaho Falls, ID 83404

\section{S. Agnew}

Los Alamos National Laboratory

MS-C345, Group INC-4

P.O. Box 1664

Los Alamos, NM 87545

J. Antizzo

U.S. Department of Energy

EM-351

Trevion II

Washington, DC 20585-0002

E. C. Ashby

225 North Avenue

Boggs Chemistry Building

Georgia Institute of Technology

Atlanta, GA 30332

K. Bandyopadhyay

Building 129

Brookhaven National Laboratory

Upton, NY 11973

N. E. Bibler

Westinghouse Savannah River

Bldg. 773A, Room 108

Aiken, SC 29802
No. of

Copies

J. O. Campbell

Oak Ridge National Laboratory

P.O. Box 2008, MS 6268

Oak Ridge, TN 37831-6268

F. N. Carlson

6965 North, 5th West

Idaho Falls, ID 83401

G. R. Choppin

Department of Chemistry B-164

Florida State University

Tallahassee, FL 32306

E. D. Collins

Oak Ridge National Laboratory

P.O. Box 2008

7930, MS-6385

Oak Ridge, TN 37831-6385

P. d'Entremont

Westinghouse Savannah River

P.O. Box 616, Bldg. 703-H

Aiken, SC 29802

R. Daniels

SAIC

20030 Century Blvd.

Suite 201

Germantown, MD 20878

M. First

295 Upland Avenue

Newton Highlands, MA 02161

C. W. Forsberg

Massachusetts Institute of Technology

Room 24-109

77 Massachusetts Avenue

Cambridge, MA 02139

Distr. 1 
No. of

Copies

C. Grelecki

Hazards Research Corporation 200 Valley Rd, Suite 301

Mt. Arlington, 07856

E. J. Hart

2115 Hart Road

Port Angeles, WA 98362

P. Hogroian

SAIC

20030 Century Blvd., Suite 201

Germantown, MD 20874

E. P. Horwitz

Chemistry Division

Argonne National Laboratory

Argonne, IL 60439

A. Hoskins

WINCO, MS-5217

P.O. Box 4000

Idaho Falls, ID 83403-4000

B. S. Hudson

Lawrence Livermore National

Laboratory, L-221

P.O. Box 808

Livermore, CA 94550

M. S. Kazimi

Room 24-102

77 Massachusetts Avenue

Cambridge, MA 02139

P. Kiang

BDM, Trevion I, Suite 300

12850 Middlebrook Road

Germantown, MD 20874

L. Kovach

NUCON

P.O. Box 29246

Columbus, OH 43229
No. of

Copies

B. R. Kowalsik

Chemistry Dept. BG-10

University of Washington

Seattle, WA 98195

T. S. Kress

P.O. Box 2009

MS 8088, Building 9108

Oak Ridge, TN 37381

T. E. Larson

Los Alamos National

Laboratory, M-1

MS C-920, P.O. Box 1663

Los Alamos, NM 87545

D. Meisel

Argonne National Laboratory

9700 South Cass Avenue

Argonne, IL 60439

D. T. Oakley

Los Alamos National Laboratory

University of California,

Suite 310

409 12th Street, SW

Washington, DC 20024-2188

F. L. Parker

Vanderbilt University

P.O. Box 1596, Station B

Nashville, TN 37235

D. Ploetz

West Valley Nuclear Services Co.

P.O. Box 191, MS 305

West Valley, NY 14171-0191

G. Powers

Design Science Inc.

163 Witherow Road

Sewickely, PA 15143

M. Reich

Building 129

Brookhaven National Laboratory

Upton, NY 11973

Distr. 2 
No. of

Copies

G. A. Russell

Department of Chemistry

Iowa State University

Ames, lowa 50011-3111

J. Saveland

20030 Century Blvd., Suite 201

Germantown, MD 20874

G. E. Schmauch

Air Products \& Chemicals, Inc. 7201 Hamilton Blvd.

Allentown, PA 18195-1501

\section{A. Schneider}

Massachusetts Institute of Technology

Department of Nuclear Engineering

Room 24-108

77 Massachusetts Avenue

Cambridge, MA 02139

W. W. Schulz

727 Sweetleaf Drive

Wilmington, DE 19808

B. Schutte

EG\&G Idaho, Inc.

P.O. Box 1625

Idaho Falls, ID 83415-3940

D. D. Siemer

WINCO

IRC, MS 2207

Idaho Falls, ID 83403

S. E. Slezak

Sandia National Laboratories,

Division 6463

P.O. Box 5800

Albuquerque, NM 87185

H. Sullivan

Los Alamos National

Laboratory, N-6, MS-K557

P.O. Box 1664

Los Alamos, NM 87545
No. of

Copies

H. Sutter

SAIC

20030 Centry Blvd., Suite 201

Germantown, MD 20878

T. Temple

U.S. Department of Energy, Bldg. 703-H/115

P.O. Box A

Aiken, SC 29801

W. J. Thomson

Department of Chemical Engineering

Washington State University

Pullman, WA 99164

E. Tuthill

Brookhaven National Laboratory

Upton, NY 11973

\section{A. S. Veletsos}

5211 Paisley

Houston, TX 77096

G. B. Wallis

Thayer School of Engineering

Darmouth College

Hanover, NH 03755

H. Walter

U.S. Department of Energy

EM-343

Trevion II

Washington, DC 20585-0002

M. Walter

U.S. Department of Energy

EM-35

Trevion II

Washington, DC 20845-0002

D. Wiffen

U.S. Department of Energy

EM-35

Trevion II

Washington, DC 20585-0002

Distr.3 
No. of

Copies

G. Woodall

U.S. Department of Energy, MS-1139

785 DOE Place

Idaho Falls, ID 83402

\section{ONSITE}

5 DOE Richland Field Office

R. F. Christensen, A4-02

R. E. Gerton, A5-21

G. Rosenwald, A5-21

B. J. Tucker, A4-35

Reading Room A1-65

33 Westinghouse Hanford Company

J. H. Appel, S4-58

R. P. Anantatmula, R2-11

H. Babad, B2-15

D. B. Bechtold, T6-50

W. F. Brehm, N2-01

T. M. Burke, H0-34

R. J. Cash, B3-68

C. Defigh - Price, R2-31

J. C. Fulton, R2-31

K. A. Gasper, B3-68

H. D. Harmon, R2-52

D. L. Herting, T6-50

J. D. Hopkins, R2-08

G. D. Johnson, L5-03 (5)

N. W. Kirch, R2-11

W. L. Knecht, H0-34

J. W. Lentsch, R2-78
No. of

Copies

R. M. Marusich, H5-32

N. G. McDuffie, R2-78

W. C. Miller, B1-58

J. C. Person, T6-50

J. G. Propson, R2-18

D. A. Reynolds, R2-11 (5)

M. H. Shannon, B1-35

D. D. Stepnewski, N1-31

53 Pacific Northwest Laboratory

R. T. Allemann, K5-19

R. M. Bean, P8-08

S. A. Bryan, P7-35

L. L. Burger, P7-25

J. A. Campbell, P8-08

J. B. Colson, K5-10

S. C. Goheen, P8-08

R. T. Hallen, P8-38

D. K. Hilliard, K2-50

B. M. Johnson, Jr., K5-02

M. R. Kreiter, K7-90

D. K. Lemon, K2-28

G. B. Mellinger, P7-18

L. G. Morgan, P8-07

L. R. Pederson, K2-44

R. D. Scheele, P7-25

G. F. Schiefelbein, P8-38

J. C. Spanner, K2-31

D. M. Strachan, K2-44 (25)

R. W. Stromatt, P7-22

D. S. Trent, K1-82

H. H. Van Tuyl, P7-22

T. W. Wood, K6-47

Publishing Coordination

Technical Report Files (5) 

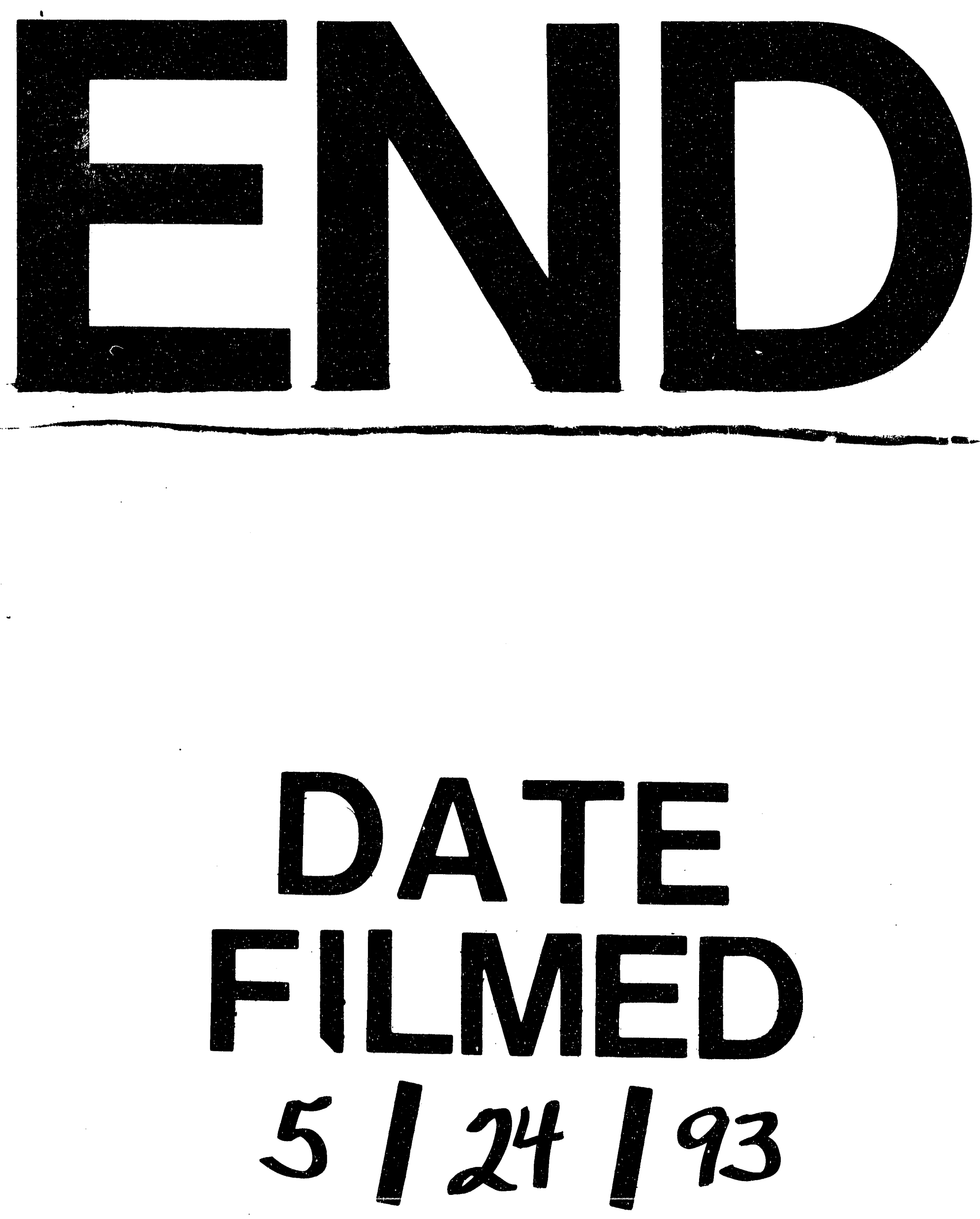
